\title{
Simulations of Nitrate Leaching from Sugarcane Farm in Metahara, Ethiopia, Using the LEACHN Model
}

\author{
Haile Arefayne Shishaye \\ Haramaya University, Dire Dawa, Ethiopia \\ Email: haile.4.hiwot@gmail.com
}

Received 25 March 2015; accepted 27 June 2015; published 30 June 2015

Copyright (c) 2015 by author and Scientific Research Publishing Inc.

This work is licensed under the Creative Commons Attribution International License (CC BY). http://creativecommons.org/licenses/by/4.0/

(C) (i) Open Access

\begin{abstract}
Metahara is the largest sugarcane farm in Ethiopia. It produces around 120,000 tons of sugar per year. The farm has been facing some problems such as salinity and sodicity, which has been studied by different experts for several decades. However, the other universal problem of agricultural farms is nitrate leaching loss, which has never been studied in the site, owing to lack of resources and expertise. The amount of nitrate leaching from agricultural farms can be measured directly from drainage rates or estimated by using numerical models. Measurements of drainage flow can be done by using lysimeters, but normally it can be estimated from water balance calculations or from field measurements of hydraulic gradients and hydraulic conductivities. However, in reality, hydraulic conductivity is highly variable and measurements in the field can be very laborious. Moreover, predicting nitrate leaching losses by using numerical models from such datapoor study area is also another problem. Nevertheless, groundwater nitrate concentration of the farm is measured by using the UV screening and distillation methods. Using the experimental results as an input for the model calibration, the amount of nitrate leaching from the farm is predicted for a 47 years of simulation period using the LEACHN model. In this case, both the measured and predicted values of nitrate leaching losses show that there is no nitrate problem in the site. However, even though the likelihood of detecting nitrate contamination in the study area is low, potential anthropogenic nitrogen sources must be carefully managed, for it is better to be safe than regretful.
\end{abstract}

\section{Keywords}

Nitrate Leaching, Groundwater Contamination, LEACHN, Sugarcane, Maximum Contaminant Level, Groundwater Protection Measures 


\section{Introduction}

Nitrate is an inorganic compound which can be man-made or a natural contaminant in groundwater and drinking water supplies. The downward movement of this contaminant due to rain and irrigation water is called nitrate leaching. Leaching may also refer to the practice of applying excess irrigation water to avoid salts from building up in the soil profile. However, in this case, drainage may be necessary to carry away the excess water. Soil texture and structure, crop type and cropping system, type and application rate of fertilizers are some of the factors affecting nitrate leaching [1].

Nutrient loss from agricultural farms in general is an increasing concern worldwide [2] [3]. Nitrate leaching in particular is a problem in many agricultural areas [2]-[5]. Modern agriculture is based on the notion that nitrate is the main source of nitrogen $(\mathrm{N})$ for crops. Yet, nitrate is also the most mobile form of $\mathrm{N}$ and easily loses from soil [6]. Efficient acquisition of nitrate by crops is a prerequisite for avoiding off-site $\mathrm{N}$ pollution [7]. The nitrate uptake capacity of some crops may be high, while it could also be considerably low for some of the crops like sugarcane. Therefore, the variations in nitrate and water uptake capacity of crops create a difference in the amount of nitrate leaching to the underlying groundwater and downstream surface water bodies [7]-[9].

According to [10], sugarcane has a preference for ammonium and a low capacity to use nitrate during periods of high $\mathrm{N}$ availability [2]. Sugarcane differs from grain crop, sorghum and maize, which acquires both $\mathrm{N}$ sources equally well [10]. Nitrogen fertilizer recovery by sugarcane is comparatively low and ranges from $20 \%$ to $40 \%$ with up to $65 \%$ of applied $\mathrm{N}$-fertilizer lost from the sugarcane soil system [2] [10]. These losses occur via pathways that include ammonia volatilization, gaseous emissions through microbial conversion of ammonium and nitrate, and nitrate leaching [10] [11].

A nitrate in groundwater and drinking water supplies is mainly a great concern for infants less than six months old, pregnant and nursing women [3] [12]. The most common symptom of nitrate poisoning is a bluish color to the skin, particularly around the baby's eyes and mouth [13]. High nitrate in drinking water is also a concern for young and pregnant animals [13]. Even though neither the chronic nor the immediate health effects of $\mathrm{N}$-nitrosamines are well understood yet, nitrate can also cause cancer when it interacts with organic compounds (secondary amines) to form $\mathrm{N}$-nitrosamines, which are known to cause cancer [13] [14].

Furthermore, nitrate leaching also has environmental problems. The environmental problems caused by the availability of inorganic nitrogen in aquatic ecosystems including water acidification, eutrophication and toxicity issues for animals including humans. In general, nitrate leaching is responsible for the main environmental impact of nitrogen fertilizer applications on water quality in all over the world [3] [15]. Therefore, groundwater and drinking water supplies, especially those nearby to agricultural farms should be tested for their nitrate contents periodically.

One of the largest sugarcane farms in Ethiopia is thus the Metahara sugarcane farm. It started production in 1966. It produces around 120,000 tons of sugar per year. The farm has been facing some problems such as salinity and sodicity, which has been studied by different experts for several decades. The other main issue that should be known in an agricultural production for an environmentally, economically and socially suitable agricultural sector is the nitrate leaching loss. However, nitrate leaching from Metahara sugarcane farm has never been quantified so far, owing to lack of equipment and expertise; while, it is expected to contaminate the underlying groundwater and pollute the downstream surface water bodies, for the majority of the farm $(10,000$ ha of the total 10,130 ha) is covered by sugarcane.

Nevertheless, direct measurement/quantification of nitrate leaching is difficult. Direct methods may require the measurement of drainage rate and its nitrate concentration [16]. Direct measurement of drainage flow is only possible using lysimeters, but normally it can be estimated from water balance calculations or from field measurements of hydraulic gradients and hydraulic conductivity [15] [17]. However, in reality, hydraulic conductivity is highly variable and measurements in the field could be very laborious [18].

Thus, prediction of nitrate leaching from the agricultural land is crucial to know the current, short term and long term contributions of nitrate leaching loss to the surface water pollution, water quality degradation and groundwater contamination. The alternative method of predicting nitrate leaching is to estimate it with the use of computer simulation models [19]. Accurate modeling of nitrate leaching requires simulations of both the soil hydrological and biogeochemical processes [18].

Therefore, the objectives of this study were to predict the long term (47 years (1966-2013)) nitrate leaching loss from the Metahara sugarcane farm to the underlying aquifer, to provide feedbacks on the nitrate leaching 
problems and recommend some appropriate groundwater protection practices. The approach chosen and applied in this simulation was the one-dimensional LEACHM model [20]. In this case, predictions were conducted based on land uses (Figure 1).

\section{The LEACHN Model}

LEACHM is one of the widely used computer simulation models for nitrate leaching estimation. It is a one-dimensional model of water and solute movement, chemical reactions and transformations, and plant uptake in the unsaturated zone [21]. The LEACHM model is written in FORTRAN and utilizes numerical solution techniques in which water flow is based on solution of Richard's equation and solute movement is based on solution of a convection-dispersion equation including source and sink terms. Water flow in LEACHM (for transient vertical soil water flow based on the 1-dimensional Richard's equation) is derived from Darcy's Law and the continuity equation. A finite difference approximation solves the Richard's equation for water flow. The model requires empirical functions relating fractional volumetric water content $(\theta)$, pressure potential $(H)$, and hydraulic conductivity $(K)$.

Darcy's law was developed for saturated flow in porous media; to this Richards applied a continuity requirement and developed a general partial differential equation describing water movement in unsaturated soils. The transient state form of this flow equation is then known as Richards's equation:

$$
\frac{\partial \theta}{\partial t}=\frac{\partial}{\partial z}\left[K(\theta) \frac{\partial H}{\partial z}\right]-U(z, t)
$$

where, $K=$ is the hydraulic conductivity (mm/day), $H=$ hydraulic potential (matric and gravitational potential) $(\mathrm{mm}), z=\operatorname{depth}(\mathrm{mm}), \theta=$ is the volumetric water content $\left(\mathrm{m}^{3} / \mathrm{m}^{3}\right)$, and $t=$ is time (day). $U=$ sink term which indicates water lost per unit time by transpiration ( $\mathrm{mm} /$ day).

Richards equation is then equivalent to the groundwater flow equation, which is in terms of hydraulic head $(h)$, by substituting $h=H+z$, and changing the storage mechanism to dewatering. The reason for writing it in the form above is for convenience with boundary conditions (often expressed in terms of pressure head, for example atmospheric conditions are $H=0$ ).

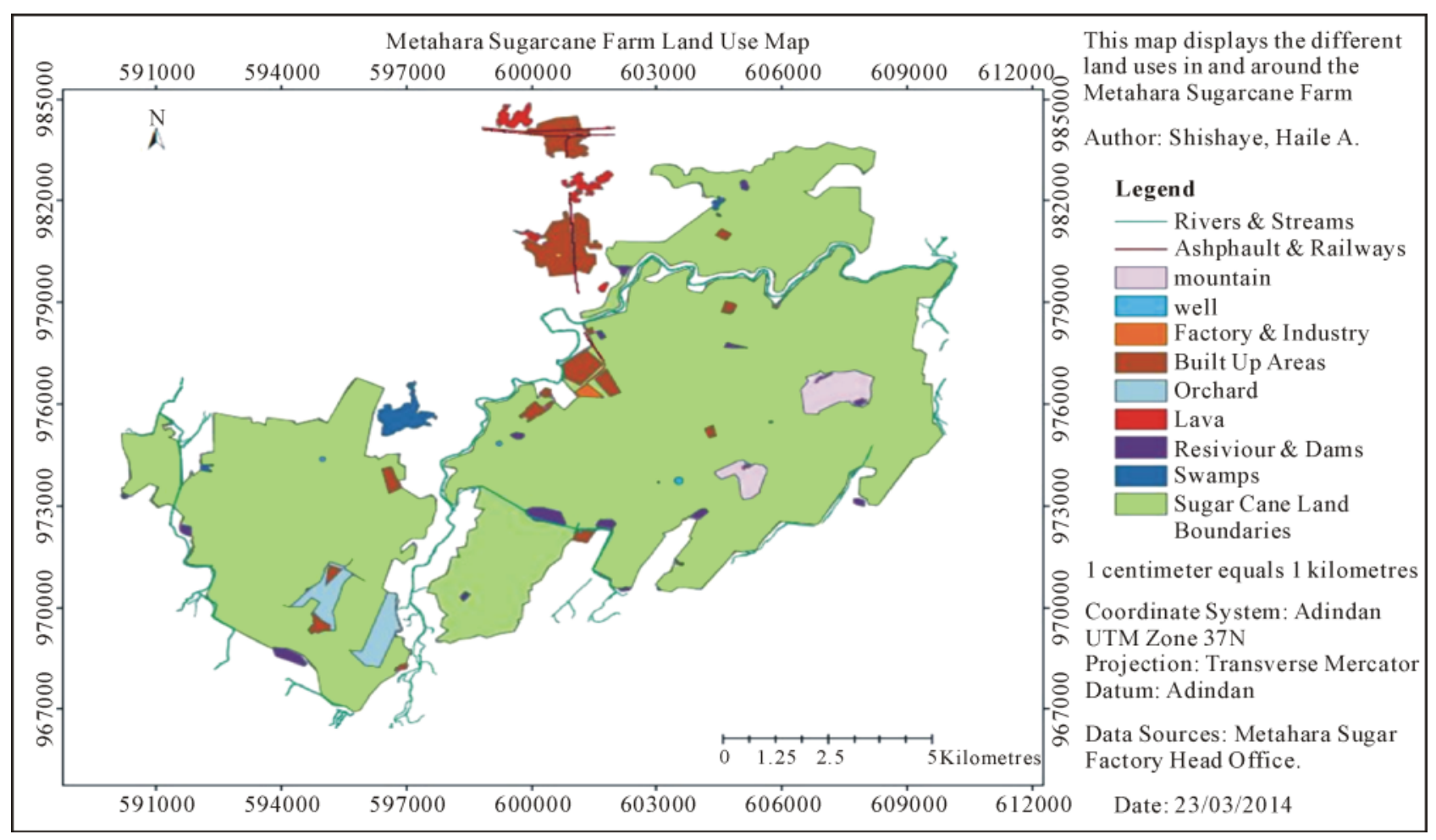

Figure 1. Land use map of Metahara sugarcane farm. 
As described above, the solute movement in the LEACHM model is based on solution of convection-dispersion equation including the source and sink terms [21]. The equation is written as follows:

$$
\frac{\partial c L \theta}{\partial t}=\frac{\partial}{\partial z}\left[\theta D(\theta, q) \frac{\partial c L}{\partial z}-q c L\right]+\Phi
$$

where, $c L=$ solution concentration, $\Phi=$ source and/or sink term, $D=$ effective dispersion coefficient, $q=$ water flux density, $z=$ distance and $t=$ time.

Currently, the model uses water retention functions based on those proposed by Campbell [22] and modified by Hutson and Cass [23]. The Hutson and Cass modified water retention equation is given as:

$$
h=\frac{a\left(1-\frac{\theta}{\theta_{s}}\right)^{1 / 2}\left(\frac{\theta_{c}}{\theta_{s}}\right)^{-b}}{\left(1-\frac{\theta_{c}}{\theta_{s}}\right)^{1 / 2}}
$$

where $\theta$ is the volumetric water content, $\theta_{s}$ is the volumetric water content at saturation, $h c, \theta_{c}$ is the point of intersection of the exponential and parabolic curves, " $a$ " and " $b$ " are empirical constants, and

$$
h_{c}=a\left(\frac{2 b}{1+2 b}\right)^{-b}
$$

and

$$
\theta_{c}=\frac{2 b \theta_{s}}{(1+2 b)}
$$

The constant " $a$ " is sometimes regarded as an air-entry value and is usually obtained by curve-fitting, but does not have any physical significance [22].

In LEACHM, the hydraulic conductivity of the soil is also described by the Campbell's conductivity equation (Campbell 1974). i.e.,

$$
K(\theta)=K_{s}\left(\theta / \theta_{S}\right)^{2 b+2+P}
$$

where, $K=$ hydraulic conductivity, $K_{s}=$ hydraulic conductivity at saturation, $P=$ pore interaction parameter.

LEACHM denotes all versions, and LEACHC, LEACHN, LEACHP and LEACHB specify the salinity, nitrogen, pesticides and microbial growth sub-models, respectively [21]. The LEACHN model simulates vertical nitrogen movement within the unsaturated soil profile. It considers a soil profile with a series of separate horizontal layers, each with its own physical, water retention and content characteristics and nitrogen content. LEACHN allows the role of vegetation, water uptake and nutrient cycling, to be incorporated into the soil profile. Water inputs into the profile can be from rainfall and irrigation, and nutrient inputs can be from fertilizer application or other amendments. Water losses from the profile such as runoff, evapotranspiration and leaching are also incorporated in the model. Therefore, nutrient losses can be through runoff, gaseous losses or leaching. Graphically, nutrient cycling in LEACHN is represented as shown in Figure 2.

\section{Materials and Methods}

\subsection{Model Input Data Collection}

\subsubsection{Rate Constants and Initial Nitrogen Concentrations}

The model input data, describes soil properties for each layer, crop growth and phonological data, soil management information, meteorological data, $\mathrm{N}$ transformation and their rate constants, and boundary conditions. Some of the important rate constants used in the model, such as the $\left(\mathrm{NH}_{4} \mathrm{~N}\right)$ partition coefficient, $\left(\mathrm{NO}_{3} \mathrm{~N}\right)$ partition coefficient, and some other model input parameters, such as the $b$ parameter in Campbell equation, Q10, air-entry value in the Campbell equation and molecular diffusion coefficient were obtained from published sources and some of them were suggested by the model developers. 


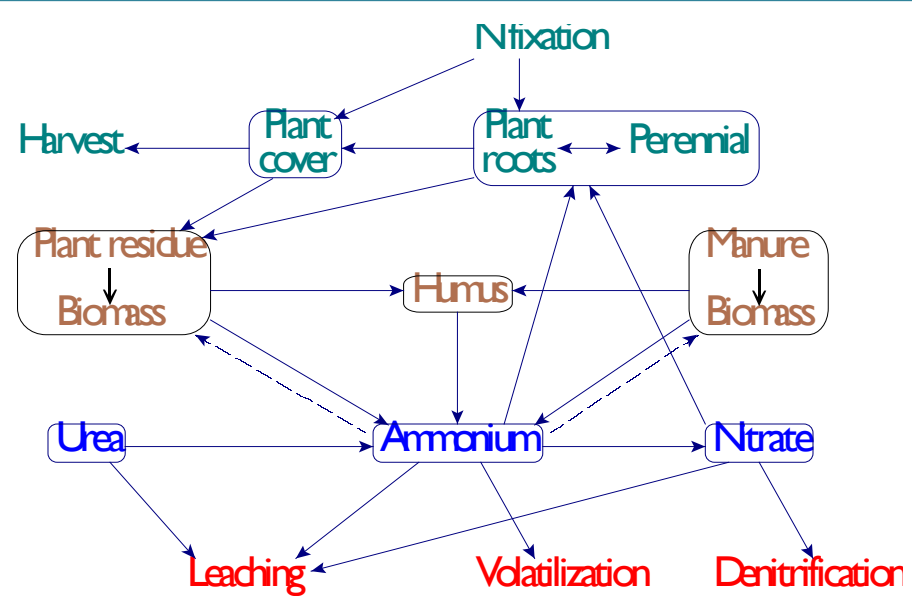

Figure 2. Nitrogen cycling in LEACHN.

The organic nitrogen pool within a soil profile is significantly influenced by the initial conditions that are estimated for organic carbon content in the soil. Estimating the initial nitrogen and carbon content in the soil profile was one of the most important activities in this simulation. In order to get the starting values of nitrogen and carbon from residue and humus, the model was run for 47 years of simulation period with 20 numbers of repetitions, until the value of nitrogen and carbon become constant. Then, those values of nitrogen and carbon were taken as initial values from residues and humus. Finally, after filling the necessary input data, simulation was conducted for 47 years of simulation periods and the model results were analyzed accordingly.

\subsubsection{Secondary Data Collection and Interpretation}

\section{1) Irrigation Practice}

There are different types of irrigation practices. The type of irrigation practice used in the study area is surface irrigation (furrow irrigation system for sugarcane and basin irrigation system for orchard crops). The dimensions of the furrow are $100 \mathrm{~m}$ in length, $60 \mathrm{~cm}$ in width and $30 \mathrm{~cm}$ in depth.

The main source of water for the farm is taken by means of diversion structure/weir from the Awash River, upstream of the farm and which has an elevation of around $985 \mathrm{~m}$ ASL. All of the weir structures are constructed across the Awash River in a concrete type. Because the source of irrigation water is river water, it has a continuous flow. The diverted water from the main course of the Awash River is stored in the night storage reservoirs for 15 hours. So, during irrigation times, the farm is irrigated for 9 hours, using the stored water in the night storages. And the process continues similarly for the next irrigation times. The irrigation water application is $40 \mathrm{~L} / \mathrm{sec} / \mathrm{ha}$. According to the information obtained from the head office of the enterprise, the field irrigation efficiency is $60 \%$ and the conveyance efficiency is $85 \%$. The irrigation interval, even though it varies based on the soil type and some other factors, is taken as an average of 15 days.

\section{2) Land Use and Fertilizer Application Practice}

According to the information obtained from the head office of MSF, the total irrigated land coverage of Metahara sugarcane farm is 10,130 ha. Of the total area, 10,000 ha is covered by sugarcane and the remaining 130 ha is covered by some other orchard fruits. The farm is divided into different irrigation units. One irrigation unit covers 64 ha of land.

Information about the fertilizer application practice was also obtained from the detailed soil re-evaluation survey conducted in the study area by Booker Tate Ltd in 2009 [24]. Although urea is currently being used to some extent in Metahara sugarcane farm, all $\mathrm{N}$ fertilizers are applied as Ammonium Sulfate Nitrate (ASN). ASN is a nitrogen fertilizer, formed by the mixture of ammonium sulphate $\left(\mathrm{NH}_{4}\right)_{2} \mathrm{SO}_{4}$ and ammonium nitrate $\left(\mathrm{NH}_{4} \mathrm{NO}_{3}\right)$. It contains $26 \% \mathrm{~N}$ and $13 \%$ Sulfur in a sulfate form [25].

Even though the nitrogen fertilizer application varies based on the soil types and some other factors, the average rates of fertilizer applications in Metahara sugarcane farm are $400 \mathrm{~kg} / \mathrm{ha}$ of (ASN) for sugarcane plant, $500 \mathrm{~kg} / \mathrm{ha}$ of ASN for the first and second ratoon crops and $600 \mathrm{~kg} / \mathrm{ha}$ of ASN for the third ratoon crops [24]. This implies that the fertilizer application interms of nitrogen is $104 \mathrm{~kg} \mathrm{~N} / \mathrm{ha}$ for sugarcane plant, $130 \mathrm{~kg} \mathrm{~N} / \mathrm{ha}$ for the first and second ratoon crops and $156 \mathrm{~kg} \mathrm{~N} / \mathrm{ha}$ for the third ratoon crops. The method of calculating the 
amount of nitrogen from the ASN fertilizer is by just taking $26 \%$ of the values of the ASN fertilizer, for ASN has $26 \%$ of nitrogen content. Thus, these three fertilizer application values were used in the simulation processes. The reason for applying less $\mathrm{N}$ in the sugarcane plant than the ratoon crops is because of that land preparation operations lead to additional mineralization of soil $\mathrm{N}$.

The other type of nutrient to be considered in an agricultural production is phosphorus (P). The amount of phosphorus being applied in the study area is $60 \mathrm{~kg} \mathrm{P} / \mathrm{ha}$ for all replant fields and $30 \mathrm{~kg} \mathrm{P} / \mathrm{ha}$ for ratoon crops. As an alternative source of nutrients the enterprise sometimes uses $50 \mathrm{t} / \mathrm{ha}$ of filter cakes, which can produce $60 \mathrm{~kg}$ $\mathrm{P} /$ ha. However, in this case, additional inorganic nitrogen fertilizer is added, for the excess $\mathrm{N}$ can be used to keep a balance on the carbon to nitrogen ratio. The carbon to nitrogen ratio (C:N) in the study area is 20:1 [24].

\section{3) Soil Property Data}

The soil physical property data is also one of the major inputs of the LEACHN model. A detailed soil survey was conducted in the study area by Booker Tate Ltd. in 2009 [24]. The soil property data used as an input for the model were then taken from the Metahara sugarcane farm main soil re-evaluation report. The soil property data used in this simulation is summarized in Table 1.

\section{4) Meteorological Data}

The important meteorological data for the LEACHN model are precipitation, temperature, evaporation and evapotranspiration. The long-term monthly meteorological data of the site were obtained from the head office of the MSF. The average monthly rainfall was fairly distributed into the number of rainy days, for the numbers of rainy days were known. This was done because of the daily meteorological data was not fully documented; otherwise, using the daily data would have been better instead. Similarly, the other necessary meteorological information was also taken from the monthly average data. Because of the weekly reference ET and mean temperature values were used, the monthly data was divided by 4 to get the weekly average data. Furthermore, the reference evapotranspiration were estimated from the class "A" pan evaporation value.

There are different methods to estimate the reference crop evapotranspiration $\left(E T_{0}\right)$. One of the common methods used is converting the class " $A$ " pan evaporation $\left(E_{\text {Pan }}\right)$ into $E T_{0}$ by using a pan coefficient $\left(K_{P a n}\right)$ [26]. In pan method, the following relationship is used:

$$
E T_{0}=K_{p a n} * E_{p a n}
$$

where, $E T_{0}$ is the reference crop evapotranspiration $\left(\mathrm{mm} \mathrm{day}^{-1}\right), E_{\text {pan }}$ is the measured class A pan evaporation (mm day ${ }^{-1}$ ) and $K_{\text {pan }}$ is the pan coefficient [27]. The pan coefficient value varies due to different conditions. i.e., it is highly dependent on the surrounding conditions. However, the average $K_{p a n}$ value is taken as 0.7 [27]. The above equation was used to estimate the reference evapotranspiration for the site, which is one of the major input data for the LEACHN model.

\section{5) Crop Data}

The main crop type grown in the study area is sugarcane. The average production of the farm is 120,000 tons of sugar per year. This implies that the production is 12 tons per year per hectare of irrigated field. The rate of $\mathrm{N}$

Table 1. Soil property data.

\begin{tabular}{|c|c|c|}
\hline & Soil physical properties & Values used \\
\hline & Particle density $\left(\mathrm{kg} / \mathrm{dm}^{3}\right)$ & 2.65 \\
\hline & Bulk density $\left(\mathrm{kg} / \mathrm{dm}^{3}\right)$ & 1.3 \\
\hline & Organic carbon (mass \%) & 1.5 \\
\hline & Hydraulic conductivity (mm/d) (only for the simulations based on land use) & 200 \\
\hline \multirow[t]{5}{*}{ Soil profile } & Profile thickness (mm) & 1600 \\
\hline & Segment thickness (mm) & 100 \\
\hline & Dispersivity $(\mathrm{mm})=$ between 0.5 to 2 times of the segment thickness & 100 \\
\hline & Clay (\%) (only for the simulations based on land use) & 55 \\
\hline & Silt (\%) (only for the simulations based on land use) & 25 \\
\hline
\end{tabular}


fertilizer addition on the farm is $104 \mathrm{~kg} \mathrm{~N} / \mathrm{ha}$ for sugarcane plant, $130 \mathrm{~kg} \mathrm{~N} / \mathrm{ha}$ for first and second ratoon crops and $156 \mathrm{~kg} \mathrm{~N} / \mathrm{ha}$ for the third ratoon crops [24]. This shows that the rate of $\mathrm{N}$ application on the farm is $8.667 \mathrm{~kg}$ $\mathrm{N} \mathrm{t}^{-1}$ cane for sugarcane plant, $10.83 \mathrm{~kg} \mathrm{~N} \mathrm{t}^{-1}$ cane for the first and second ratoon crops and $13 \mathrm{~kg} \mathrm{~N} \mathrm{t}^{-1}$ canes for the third ratoon crops. However, according to different literatures, the nutrient uptake capacity of sugarcane is very low, $2.8 \mathrm{~kg} \mathrm{~N} \mathrm{t}^{-1}$ cane [28]. Therefore, in this case, the target nitrogen uptake for sugarcane was taken as (12 ton cane ha ${ }^{-1} * 2.8 \mathrm{~kg} \mathrm{~N} \mathrm{t}^{-1}$ cane) $33.6 \mathrm{~kg} \mathrm{~N} / \mathrm{ha}$.

\subsubsection{Field Observation and Measurements}

The nitrate leaching loss from the study area varies based on the land use and soil type differences. To estimate the loss of nitrate from each and every land use, a plantation map (land use map) was prepared using ArcGIS 10.1. The site was first supervised for the simplicity of the land use classifications. The boundary elevation and point elevations for some irrigation units in the study area were obtained from previous studies. Moreover, boundary elevation data for the remaining land uses (which have not been included in the previous studies) were also measured using GPS.

\subsubsection{Laboratory Measurements}

Four wells were drilled within the farm to take water samples that can fairly represent the groundwater in the study area. Groundwater samples were taken from these 4 wells for experimental purposes. Samples from every well were then experimented for their nitrate and ammonium concentrations in "JIJE LABOGLASS P.L.C", Addis Ababa, Ethiopia.

The test methods used to experiment the nitrate nitrogen concentration of the water samples were APHA 4500- $\mathrm{NO}_{3}-\mathrm{B}$, Ultraviolet Spectrophotometric screening method and Devardas distillation method. Devardas distillation method was used for the sample from Z-65 (near lake Beseka), for it was not possible to detect it using the ultraviolet screening because of the clarity of the water. While, MgO distillation method was used to test the ammonium nitrogen concentration of the samples.

The test results of each water sample are listed in Table 2. ND in Table 2 indicates for the results with less than method detection limit. As it is shown in column 5 of Table 2, the nitrate nitrogen concentration of the groundwater in the study area varies from one irrigation unit to another, especially on the sides of the farm. This could be because of the external impacts. The lower nitrate nitrogen concentration on the Z-65 irrigation unit, for example, could be due to the lake water intrusion from Lake Besseka, which has a concentration of $0.233 \mathrm{mg}$ $\mathrm{NO}_{3} \_\mathrm{N} / \mathrm{L}$. In addition, the lower $\mathrm{NO}_{3} \_\mathrm{N}$ concentration in the near factory water is also due to the Awash River water intrusion.

Hence, the nitrate nitrogen concentration values of the four samples (S/N 1-4, Table 2) were averaged to estimate the average concentration of the groundwater in the study area. Thus, the average groundwater nitrate nitrogen concentration was found to be $3.58 \mathrm{mg} / \mathrm{L}$, which is below the maximum contaminant level standard designed by WHO and USEPA, (10 mg NO $\left.\mathrm{N}_{3} \mathrm{~N} / \mathrm{L}\right)$ [29]-[31].

\subsubsection{Sensitivity Analysis}

The model was evaluated using a two year input data (01/01/1966-31/12/1967) and the results were analyzed accordingly. Much work has been done on sensitivity analysis. As a result, it was possible to identify the parameters which the model output is sensitive to, using the input parameter values shown in the Table 3 . After

\begin{tabular}{ccccc}
\multicolumn{5}{l}{ Table 2. Experimental results. } \\
\hline S/N & Lab No & Irrigation Unit & $\mathrm{NH}_{4}-\mathrm{N}(\mathrm{mg} / \mathrm{L})$ & $\mathrm{NO}_{3}-\mathrm{N}(\mathrm{mg} / \mathrm{L})$ \\
\hline 1 & $\mathrm{~J}-\mathrm{W}-0022 / 14$ & Near factory water & $\mathrm{ND}$ & 2.00 \\
2 & $\mathrm{~J}-\mathrm{W}-0023 / 14$ & $\mathrm{R}-44$ & $\mathrm{ND}$ & 5.40 \\
3 & $\mathrm{~J}-\mathrm{W}-0024 / 14$ & $\mathrm{Z}-65$ & $\mathrm{ND}$ & 1.51 \\
4 & $\mathrm{~J}-\mathrm{W}-0025 / 14$ & $\mathrm{R}-42$ & $\mathrm{ND}$ & 5.40 \\
5 & $\mathrm{~J}-\mathrm{W}-0026 / 14$ & Lake Besseka water & $\mathrm{ND}$ & 0.23 \\
6 & $\mathrm{~J}-\mathrm{W}-0026 / 14$ & Awash river water & $\mathrm{ND}$ & 0.50 \\
\hline
\end{tabular}


Table 3. Range of the values of model input parameters used for analysis in this simulation.

\begin{tabular}{cccc}
\hline Input parameter & $\begin{array}{c}\text { Range of values } \\
\text { used for analysis }\end{array}$ & $\begin{array}{c}\text { Literature } \\
\text { values }\end{array}$ & $\begin{array}{c}\text { Used in this } \\
\text { simulation }\end{array}$ \\
\hline Nitrification rate, $\mathrm{d}^{-1}$ & $0.01-0.4$ & $0.01-0.5$ & 0.1 \\
Denitrification rate, $\mathrm{d}^{-1}$ & $0.001-0.3$ & $0.001-0.1$ & 0.13 \\
Mineralization rate (humus) $\times 10^{-4}, \mathrm{~d}^{-1}$ & $1 \times 10^{-5}-0.001$ & - & $1 \times 10^{-5}$ \\
Mineralization rate (plant residue), $\mathrm{d}^{-1}$ & $0.01-0.03$ & $0.01-0.2$ & 0.01 \\
Mineralization rate (manure), $\mathrm{d}^{-1}$ & $0.01-0.03$ & $0.01-0.03$ & 0.02 \\
Ammonia volatilization rate, $\mathrm{d}^{-1}$ & $0-0.4$ & $0-0.4$ & 0.2 \\
Q10 & $1-3$ & $2-3$ & 2 \\
Air-entry value (Campbell equation) & $0.3-3$ & Vary & 1 \\
b parameter (Campbell equation) & $7-20$ & Vary & 3 \\
Partition coefficient ( $\left.\mathrm{NH}_{4}-\mathrm{N}\right), \mathrm{L} \mathrm{kg}^{-1}$ & $1-4$ & 3.0 & 0 \\
Partition coefficient ( $\left.\mathrm{NO}_{3}-\mathrm{N}\right), \mathrm{L} \mathrm{kg}^{-1}$ & 0.0 & 0.0 & 10 \\
C/N ratio for biomass and humus & 10 & 10 & \\
\hline
\end{tabular}

identifying the input parameters which the simulation result is sensitive to, suggestions for the best estimated value of some of the $\mathrm{N}$ transformation rate constants were obtained from the model developer (Dr. John Hutson, Flinders University, Australia). Some values were also obtained from literatures.

The range of values of the $\mathrm{N}$ transformation rate constants and some other model input parameters used to analyze the sensitivity of the model are listed in Table 3.

The unit gradient drainage was chosen as a lower boundary for the Richards option water flow. The reason why this type of lower boundary was selected is that in the unit gradient option, any nitrate or chemical accumulation in the profile is either due to any of the amendments or from $\mathrm{N}$ mineralization [20] [21]. i.e., there is no flow coming from the underlying groundwater in this case. However, if we take the other options as a lower boundary, water table for example, can be affected by the water which can flow upward from the underlying aquifer [32]. So, if the groundwater is contaminated with nitrate, it increases the nitrate content of the profile when it rises up, and it leaves some amount of nitrate on the profile when it falls. In this case, the unit gradient lower boundary option is the safest option to use.

As it is shown in the Figures 3-8, the LEACHN model was found very sensitive to denitrification, nitrification, mineralization (especially humus), and the $b$ parameter in the Campbell equation. Sensitivity analysis of the molecular diffusion $\left(D_{0}\right)$ and dispersivity coefficients (not included in Table 3 ), air-entry value of the Campbell's equation, and $Q_{10}$ indicated that changes in these coefficients do not have a considerable influence in the simulated model outputs.

\subsubsection{Model Calibration}

Calibration is the process of modifying the input parameters to a model until the output from the model matches an observed set of data. In this case, the average groundwater nitrate nitrogen concentration found from the laboratory measurements, $3.58 \mathrm{mg} \mathrm{NO}{ }_{3} \_\mathrm{N} / \mathrm{L}$, was used to calibrate the LEACHN model. The model input parameters were modified until the simulated nitrate nitrogen concentration matches the average experimental result.

The other data found for calibration purposes was the nitrogen stress data of the crops. There was a study conducted on the study area, by the Booker Tate Ltd. in 2009, regarding leaf N\%. They took 164 samples from the study area; of the 164 samples taken, $22 \%$ were found to be below the accepted lower limit for leaf N\% within any season (1.6\%), whilst the remainder (78\%) showed satisfactory levels of N (Figure 9). Requirements for the leaf $\mathrm{N}$ levels are, however, related to crop type and cropping season. In South Africa, for example, the threshold value has been determined to vary between up to $1.6 \%$ (for late season ratoon cane) to $1.9 \%$ (for early season plant cane) [24]. The lowest of these figures (1.6\%) has been used during the analysis. Therefore, in this 


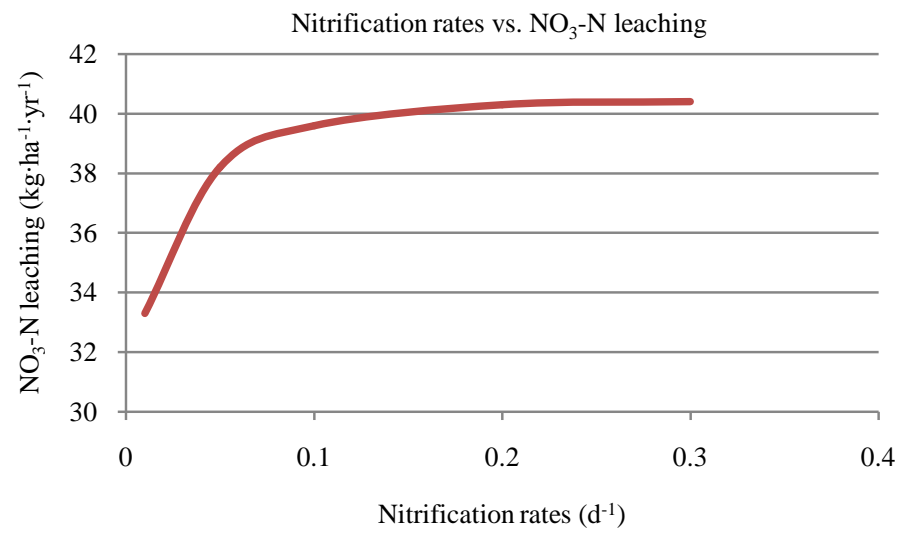

Figure 3. Sensitivity analysis of nitrification rates.

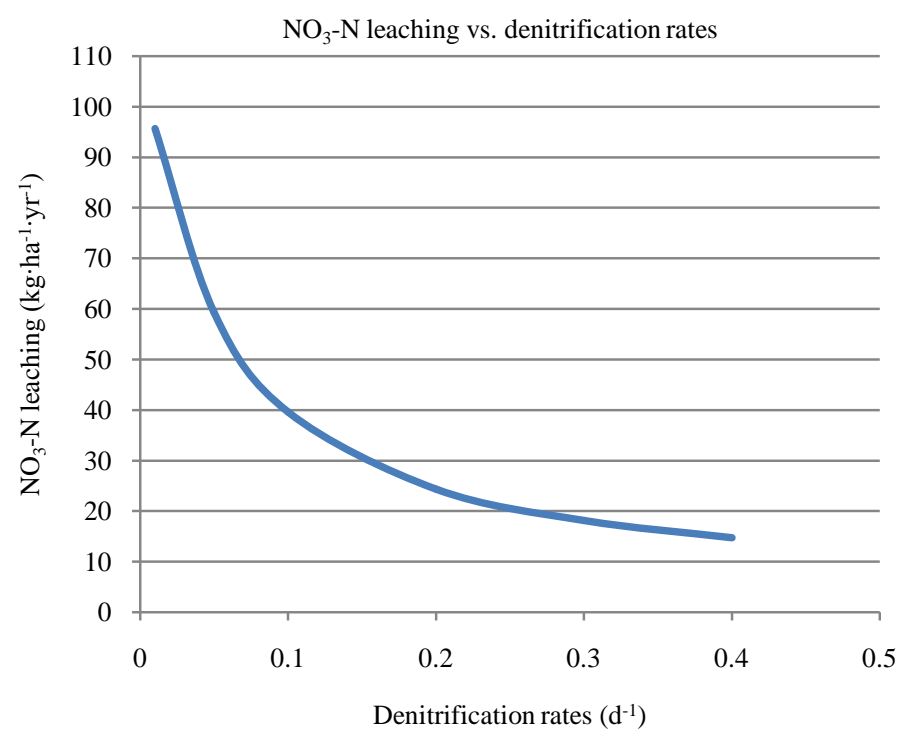

Figure 4. Sensitivity analysis of denitrification rates.

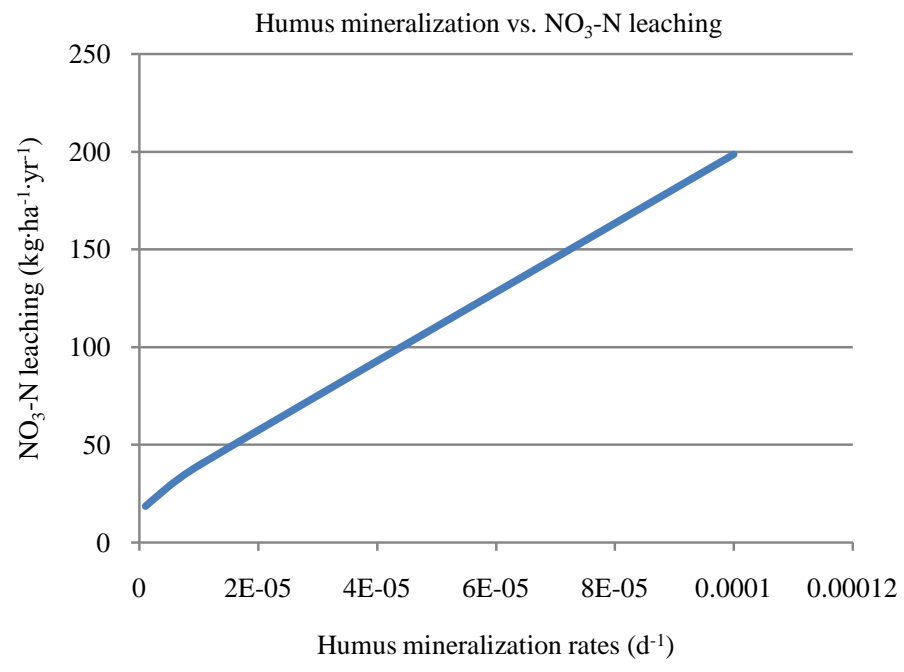

Figure 5. Sensitivity analysis of humus mineralization rates. 


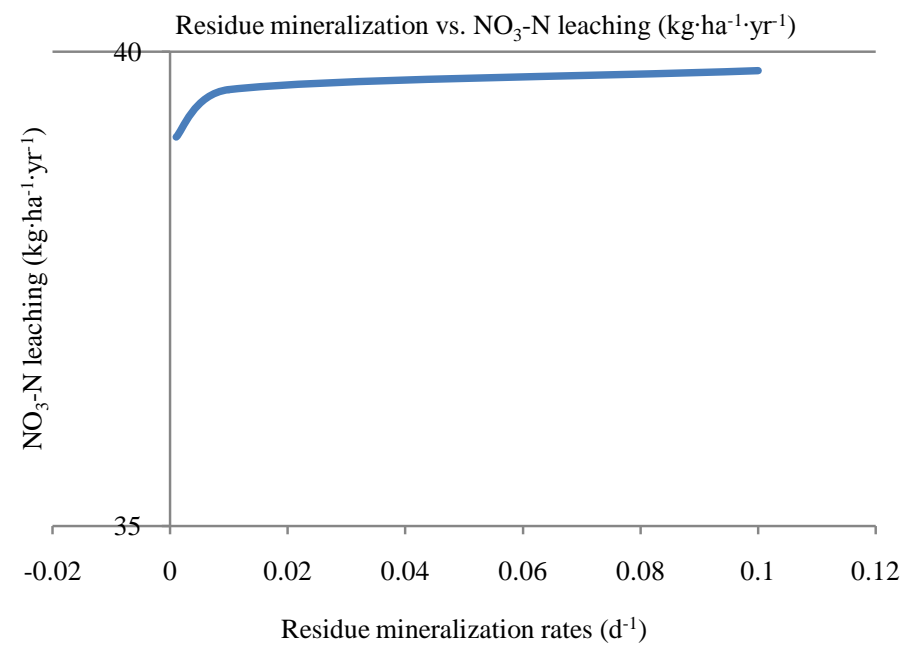

Figure 6. Residue mineralization rates.

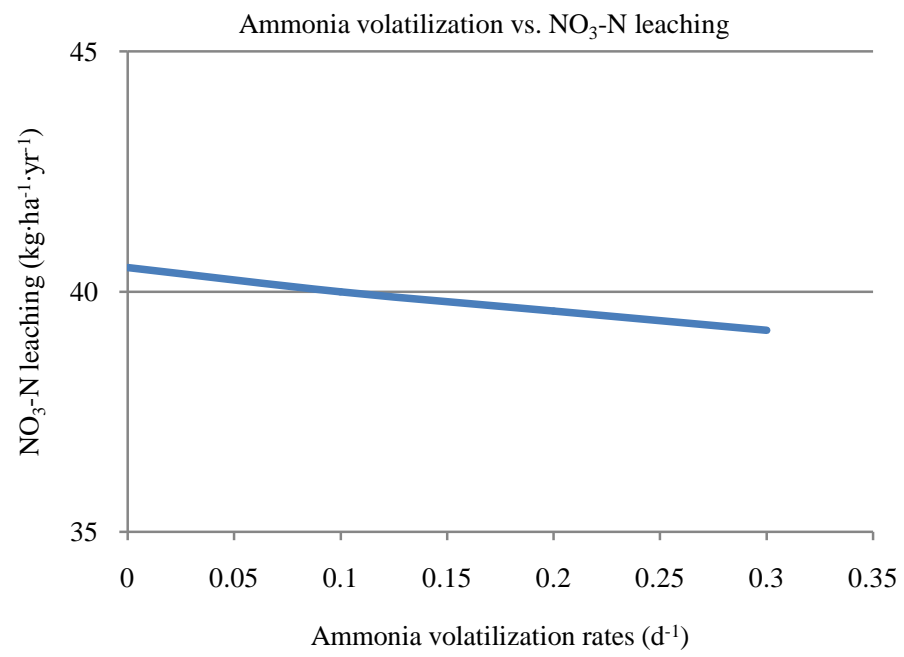

Figure 7. Ammonia volatilization rates.

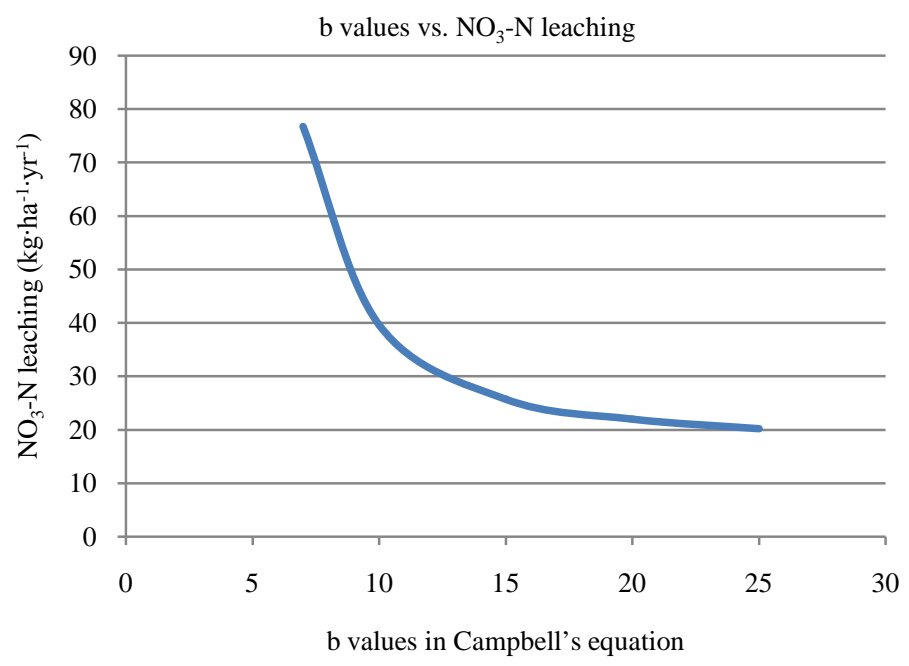

Figure 8. b parameter in the Campbell equation. 


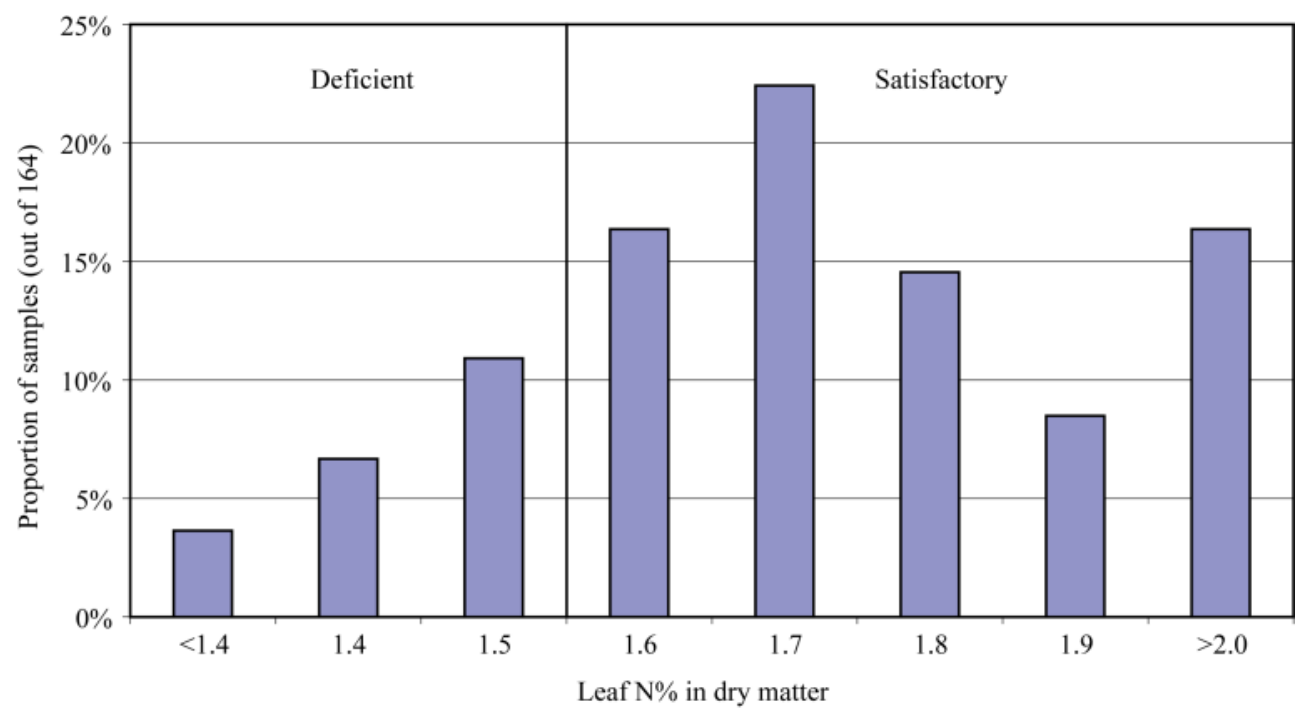

Figure 9. Distribution of leaf N\% levels in 164 leaf samples in Metahara sugarcane farm (Modified from Booker Tate 2009).

manuscript, $78 \%$ of $\mathrm{N}$ level was used as the lowest plant nitrogen uptake to target. The model was repeatedly run and the input parameters were modified until the nitrogen uptake to target values along the whole simulation periods became above $78 \%$.

\subsubsection{Equations Used for the Nitrogen Transformation Processes in LEACHN}

There are different factors that affect the values of the nitrogen transformation rate constants. One of the major factors is the $\mathrm{C}: \mathrm{N}$ ratio. The value of $\mathrm{C}: \mathrm{N}$ in the soil influences the values of the nitrogen transformation constants. For instance, the value of C:N $>30$ causes immobilization; while, C:N $<20$ causes mineralization (Jonson et al. 1993, Toride and Chen 2011). According to Hutson (2005) quoted in [33], the equations used for some of the nitrogen transformation processes are presented below:

\section{1) Mineralization}

$$
\begin{aligned}
\frac{\mathrm{d} C_{\mathrm{NH}_{4} i(p)}}{\mathrm{d} t} & =\frac{\mathrm{d} C_{\text {org_Ni }(d)}}{\mathrm{d} t}-\left(\frac{\mathrm{d} C_{\text {bioNi }(p)}}{\mathrm{d} t}+\frac{\mathrm{d} C_{\text {hum_N } N(p)}}{\mathrm{d} t}\right) \\
& =\left(\frac{1}{R_{\text {orgi }}}-\frac{f_{e i}\left(1-f_{\text {hi }}\right)}{R_{\text {bio }}}-\frac{f_{e i} f_{h i}}{R_{\text {hum }}}\right) \frac{\mathrm{d} C_{\text {org_ci }}}{\mathrm{d} t} \\
& =\left(\frac{1}{R_{\text {orgi }}}-\frac{f_{e i}\left(1-f_{h i}\right)}{R_{\text {bio }}}-\frac{f_{\text {ei }} f_{\text {hi }}}{R_{\text {hum }}}\right) K_{\text {orgi }} C_{\text {org_ci }}
\end{aligned}
$$

where, $\frac{\mathrm{d} C_{\text {org_Ni(d) }}}{\mathrm{d} t}=$ nitrogen production rate from organic mater

$\frac{\mathrm{d} C_{\text {bioni }(p)}}{\mathrm{d} t}=$ nitrogen production rate from biomass

$\frac{\mathrm{d} C_{h u m_{\_} N(p)}}{\mathrm{d} t}=$ nitrogen production rate from humus

$R_{\text {orgi }}=\mathrm{C}: \mathrm{N}$ for organic matter

$f_{e i}=$ efficiency factor

$f_{h i}=$ humification factor

$R_{b i o}=$ C: $\mathrm{N}$ for biomass

$R_{\text {hum }}=$ C:N for humus 
$\frac{\mathrm{d} C_{\text {org_ci }}}{\mathrm{d} t}=$ organic carbon production rate

$K_{\text {orgi }}=$ first order rate coefficient

2) Immobilization

$$
\Delta C_{\mathrm{NH}_{4}}=\left(\frac{1}{R_{\text {org }}}-\frac{f_{e i}}{R_{o}}\right) \Delta C_{o r g-c i}
$$

where, $\Delta C_{\mathrm{NH}_{4}}=$ the amount of immobilized $\mathrm{NH}_{4}-\mathrm{N}$ per day

$R_{\text {orgi }}=\mathrm{C}: \mathrm{N}$ for organic matter

$f_{e i}=$ the efficiency factor

$R_{o}=$ constant, sometimes expressed as $R_{o r g i}{ }^{*} f_{e i}$

$C_{\text {org-ci }}=$ organic carbon

3) Net Nitrate Production

$$
\frac{\mathrm{d} C_{\mathrm{NO}_{3}}}{\mathrm{~d} t}=-k_{\mathrm{den}} * C_{\mathrm{NO}_{3}}+K_{n i t} * C_{\mathrm{NH}_{4}}
$$

where,

$$
\begin{aligned}
& \frac{\mathrm{d} C_{\mathrm{NO}_{3}}}{\mathrm{~d} t}=\text { net nitrate production } \\
& K_{d e n} * C_{\mathrm{NO}_{3}}=\text { denitrification } \\
& K_{n i t} * C_{\mathrm{NH}_{4}}=\text { nitrification } \\
& K_{\text {den }}=\text { denitrification constant and } K_{\text {nit }}=\text { nitrification constant }
\end{aligned}
$$

\subsection{GIS Modeling}

ArcGIS 10.1 was used to develop the land use map and to show the spatial distribution of the nitrate leaching loss based on the land use differences. Using the point elevation data of the irrigation units in the farm obtained from previous studies and those measured using GPS, the land use map was developed using ArcGIS 10.1 (Figure 1).

Additionally, maps showing the change of cumulative nitrate concentration with time were prepared using ArcGIS10.1. In this case, the nitrate leaching loss values obtained from the LEACHN model were used as an input to the GIS modeling. Finally, it was possible to visually display and spatially distributes the simulation results based on land use differences using ArcGIS 10.1.

\section{Model Results and Discussion}

\subsection{Simulation Based on Land Use}

Land use is the utilization of land for different purposes such as agricultural, industrial, residential, recreational, or other purposes. The type of land use that needs to be considered in this case is agricultural land use. The agricultural land in the study area is mainly used for sugarcane and orchard farming.

\subsubsection{Model Results from the Sugarcane Farm}

The cumulative amount of nitrate nitrogen leached from the sugarcane farm to the underlying groundwater, in the 47 years of simulation period, was found to be $178.8 \mathrm{~kg} / \mathrm{ha}$, while the ammonium nitrogen and urea nitrogen leaching were found to be 1.1 and $0 \mathrm{~kg} / \mathrm{ha}$, respectively. From this, the 47 years cumulative amount of water drained from the farm was found to be $4756.4 \mathrm{~mm} / \mathrm{m}^{2}$. Now, we can calculate the nitrate nitrogen and nitrate ion concentrations of the water draining to the underlying aquifer in the study area. The first procedure to calculate the nitrate concentration in this case is to make unit conversions.

$$
\text { i.e., } 178.8 \frac{\mathrm{kg}}{\mathrm{ha}} \mathrm{NO}_{3}^{-} \mathrm{N}=\left(178.8 \frac{\mathrm{kg}}{\mathrm{ha}} * 1000000 \frac{\mathrm{mg}}{\mathrm{kg}}\right) /\left(10000 \frac{\mathrm{m}^{2}}{\mathrm{ha}}\right)=17880 \frac{\mathrm{mg}}{\mathrm{m}^{2}} \mathrm{NO}_{3}^{-} \mathrm{N} \text {. }
$$


Dividing the mass of the nutrient leached per $\mathrm{m}^{2}$ by the depth of water drained per $\mathrm{m}^{2}$ will give us the $\mathrm{NO}_{3-}^{-} \mathrm{N}$ concentration value. So,

$$
\left[\mathrm{NO}_{3-}^{-} \mathrm{N}\right]=\frac{17880 \frac{\mathrm{mg}}{\mathrm{m}^{2}}}{4756.4 \frac{\mathrm{mm}}{\mathrm{m}^{2}}}=3.76 \frac{\mathrm{mg}}{\mathrm{mm}}=3.76 \frac{\mathrm{mg}}{\mathrm{L}}
$$

The atomic weight of $\mathrm{NO}_{3}^{-}$is 62 and that of $\mathrm{N}$ is 14 . The $\mathrm{NO}_{3}^{-}$concentration can, therefore, be calculated as:

$$
\left(3.76 \frac{\mathrm{mg}}{\mathrm{L}} * 62 / 14\right)=16.65 \frac{\mathrm{mg}}{\mathrm{L}} .
$$

Moreover, the total nitrogen concentration of the water leaching to the underlying aquifer can also be calculated as follows:

$$
\begin{gathered}
{[\text { Nitrogen }]=[\text { nitrate nitrogen }]+[\text { ammonium nitrogen }]+[\text { urea nitrogen }]} \\
{[\mathrm{N}]=\left[\mathrm{NO}_{3}^{-}-\mathrm{N}\right]+\left[\mathrm{NH}_{4}-\mathrm{N}\right]+\left[\mathrm{CO}\left(\mathrm{NH}_{2}\right)_{2}-\mathrm{N}\right]=3.76 \frac{\mathrm{mg}}{\mathrm{L}}+\frac{110 \frac{\mathrm{mg}}{\mathrm{m}^{2}}}{4756.4 \frac{\mathrm{mm}}{\mathrm{m}^{2}}}+0=3.78 \frac{\mathrm{mg}}{\mathrm{L}} .}
\end{gathered}
$$

where, [] indicates for concentration.

In this case, it is assumed that the source of groundwater nitrate contamination in the study area is only from the leaching loss, for the LEACHN model was calibrated using the average measured groundwater nitrate concentration, while there could also be other sources of groundwater nitrate. Geologic formations, for example, can be considered as sources of groundwater nitrate contamination [34]. However, irrespective of the sources of groundwater nitrate, the groundwater nitrate concentration in the study area lays at the low risk standards established by the USEPA and WHO in accordance with the Safe Drinking Water Act. It can still be used for a drinking water supply, but this does not imply that there is no need for treatment before use. This inference will only answer the nitrate related threats. A detail groundwater analysis, including other parameters apart from nitrate, is needed to make an accurate conclusion regarding the usability of the groundwater in the study area.

\section{1) The Timely Variations of the Amount of Nitrate Leaching}

The amount of nitrate leaching to the underlying groundwater was found not to be constant throughout the simulation periods. The major causes for these variations are the variations in temperature, water uptake capacity of the crop, amount of added and draining water, evapotranspiration losses and some other related factors (Figure 10).

The factors affecting the rate of drainage also affect the amount of nitrate leaching. As it is shown in Figure 10 , nitrate leaching increases with the increase in drainage rate and it decreases with the decrease in drainage, for it actually occurs when nitrate leaves the soil with drainage water. Generally, nitrate leaching increases with the decrease in evapotrnspiration, decrease in plant water uptake, and increase in the amount of water added; while, the opposite causes a decrease in nitrate leaching loss (Figure 10).

\section{2) Predicted Profile Nitrate Concentration}

The 47 years leaching of nitrate from the root zone was modeled to investigate whether the nitrate concentration in drainage water could impact upon groundwater nitrate concentration or not. The predicted profile nitrate concentration (Figure 11) was calculated from the volume of drainage and the mass of nitrate leached at the final simulation period.

The soil type in the study area has the ability of storing water and nutrient for a long period of time before it joins the groundwater. Consequently, profile nitrate concentration will get high at the middle than the top part of the root zone, for the accumulation will get high over time. The profile nitrate concentration at the end of the 47 years of simulation periods (Figure 11) is then showing an increase with depth up to the top $900 \mathrm{~mm}$ of the root zone, and then it starts decreasing afterwards. This is because of that part of the amount of nitrate stored within the root zone gets lost to the atmosphere due to denitrification and immobilized back to the organic forms of nitrogen. Finally, the amount of nitrate leaching decreases (Figure 11). However, the profile nitrate concentrations 


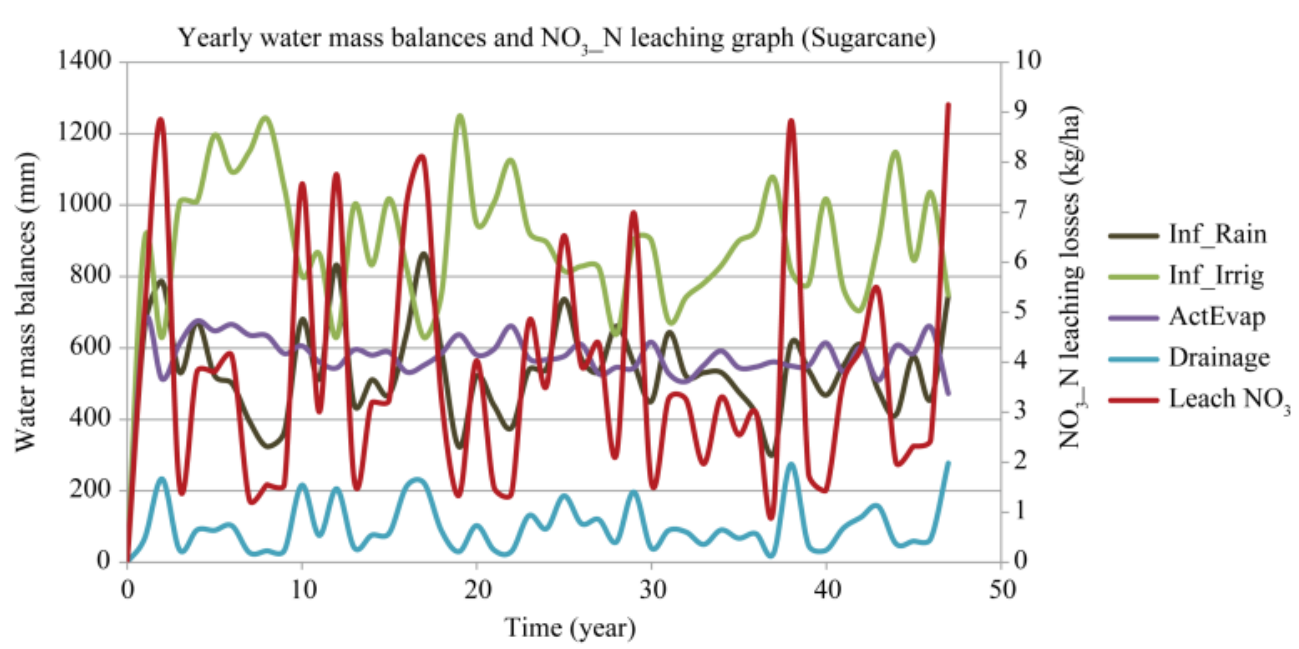

Figure 10. Yearly water mass balances and $\mathrm{NO}_{3} \_\mathrm{N}$ leaching from sugarcane farm.

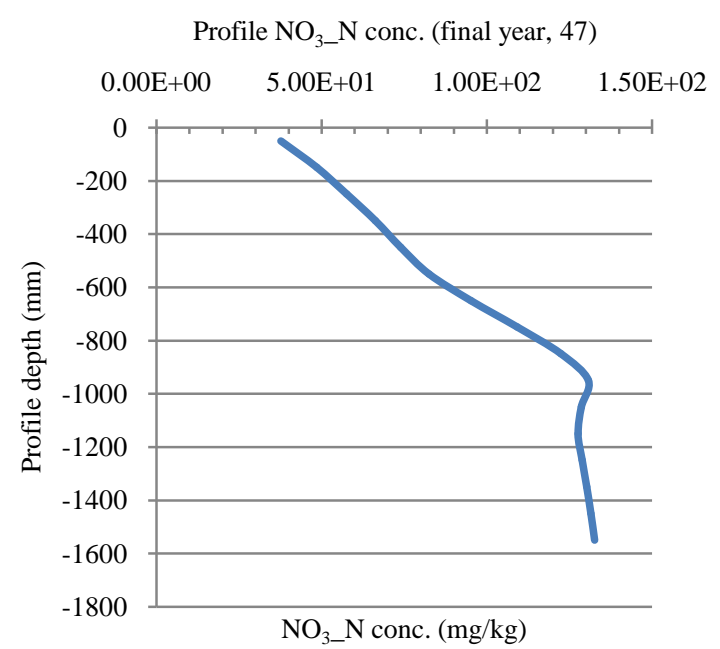

Figure 11. Profile $\mathrm{NO}_{3}-\mathrm{N}$ concentration (final, 47 years).

are theoretical, presented to describe the variability of nitrate concentrations that may occur within the profile.

\subsubsection{Model Results from the Orchard Farm}

The second type of agricultural land use on the study area is orchard farming. Around 130 ha of land in the Metahara sugar enterprise is covered by different orchard crops. According to FAO [35], the depth of the root zone of orchard crops ranges from 1 to $2 \mathrm{~m}$. Hence, the depth of the root zone which was used in this simulation is 1.6 $\mathrm{m}$, similar to the one used for sugarcane crops.

The cumulative amount of nitrate nitrogen leached from the orchard farm to the underlying aquifer can be calculated in the same manner as the leaching calculations for the sugarcane farm above. The amount of nitrate leached from the orchard farm in the 47 years of simulation period was found to be $127.8 \mathrm{~kg} / \mathrm{ha}$. Leaching values for the ammonium nitrogen and urea nitrogen were also found to be $1.0 \mathrm{~kg} / \mathrm{ha}$ and $0 \mathrm{~kg} / \mathrm{ha}$, respectively. The 47 years cumulative amount of water drained from the orchard farm was also found to be $4144.2 \mathrm{~mm} / \mathrm{m}^{2}$. Therefore, we can calculate the nitrate nitrogen and nitrate ion concentrations of the water draining to the underlying aquifer as follows. The first procedure to calculate the nitrate concentration in this case is also to make unit conversions.

$$
\text { i.e., } 127.8 \frac{\mathrm{kg}}{\mathrm{ha}} \mathrm{NO}_{3}^{-} \mathrm{N}=\left(127.8 \frac{\mathrm{kg}}{\mathrm{ha}} 1000000 \frac{\mathrm{mg}}{\mathrm{kg}}\right) /\left(10000 \frac{\mathrm{m}^{2}}{\mathrm{ha}}\right)=12780 \frac{\mathrm{mg}}{\mathrm{m}^{2}} \mathrm{NO}_{3}^{-} \mathrm{N} \text {. }
$$


Dividing the mass of the nutrient leached per $\mathrm{m}^{2}$ by the volume of water drained will give us the $\mathrm{NO}_{3-}^{-} \mathrm{N}$ concentration value. So,

$$
\left[\mathrm{NO}_{3-}^{-} \mathrm{N}\right]=\frac{12780 \frac{\mathrm{mg}}{\mathrm{m}^{2}}}{4144.2 \frac{\mathrm{mm}}{\mathrm{m}^{2}}}=3.08 \frac{\mathrm{mg}}{\mathrm{mm}}=3.08 \frac{\mathrm{mg}}{\mathrm{L}}
$$

The atomic weight of $\mathrm{NO}_{3}^{-}$is 62 and that of $\mathrm{N}$ is 14. Therefore, from this, the $\mathrm{NO}_{3}^{-}$concentration can be calculated as:

$$
\left(3.08 \frac{\mathrm{mg}}{\mathrm{L}} * 62 / 14\right)=13.64 \frac{\mathrm{mg}}{\mathrm{L}}
$$

Moreover, the total nitrogen concentration of the water leaching to the underlying aquifer can also be calculated as follows:

$$
[\mathrm{N}]=\left[\mathrm{NO}_{3}^{-}-\mathrm{N}\right]+\left[\mathrm{NH}_{4}-\mathrm{N}\right]+\left[\mathrm{CO}\left(\mathrm{NH}_{2}\right)_{2}-\mathrm{N}\right]=3.08 \frac{\mathrm{mg}}{\mathrm{L}} \frac{100 \frac{\mathrm{mg}}{\mathrm{m}^{2}}}{4144.2 \frac{\mathrm{mm}}{\mathrm{m}^{2}}}+0=3.10 \frac{\mathrm{mg}}{\mathrm{L}} .
$$

This calculation is showing that the 47 years nitrate leaching losses from both of the sugarcane and orchard farms are fairly low. However, because of the applied nitrogen fertilizer in orchard crops is lower than that of sugarcane; the nitrate leaching loss from the orchard crops is a bit smaller than that of sugarcane. Moreover, the nitrate uptake capacities of sugarcane and orchard crops are also different. Therefore, this can also be one of the reasons for the variations in nitrate leaching losses from these two different land uses. But, in a general case, the excess nitrogen fertilizer applied on the orchard and sugarcane farms usually becomes source of environmental pollution, including groundwater contamination.

\section{1) The Timely Variations of the Amount of Nitrate Leaching}

Figure 12 shows the yearly water mass balances and the variations in nitrate leaching from the orchard farm due to different factors. Similar to that of sugarcane, nitrate leaching from the orchard farming also varies with time. The factors that cause variations in the amount of nitrate leaching with time are also similar to what is discussed under section 3.1.1.1 above. Nitrate leaching varies mainly with the change in the rate of draining water.

\section{2) Predicted Profile Nitrate Concentration}

The trend of the profile nitrate concentration under the orchard farm is almost similar to that of sugarcane. Though, the values of the profile nitrate concentration at the same depth of the root zone under the sugarcane

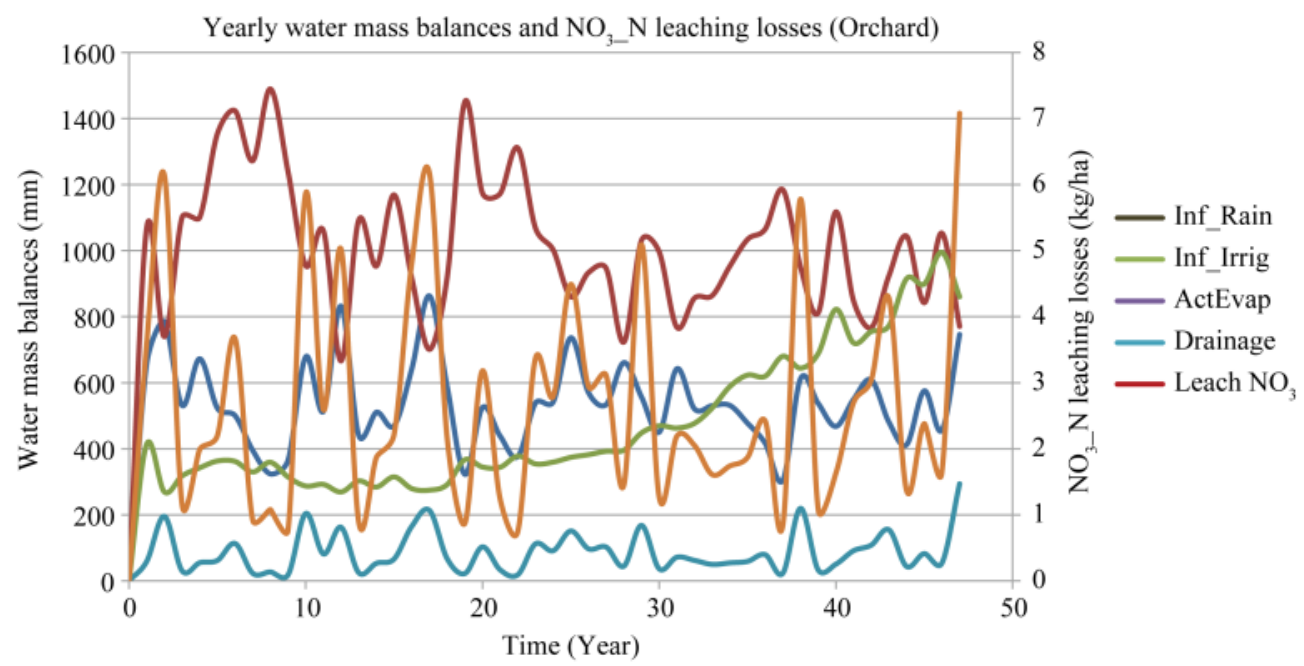

Figure 12. Yearly water mass balances and $\mathrm{NO}_{3} \_\mathrm{N}$ leaching from orchard farm. 
and orchard crops are different. This is because of the variations in the amount of nitrogen fertilizers added to the farms and the nutrient uptake capacity differences of the crops.

Generally, the profile nitrate concentration (Figure 13) is showing an increase with depth up to around 900 $\mathrm{mm}$ of the depth of the root zone, and then it starts decreasing. This is because of that nitrate gets accumulated at some depth within the root zone, for the soil type is poorly drained. Then it starts being denitrified to gaseous forms and immobilized back to the organic forms of nitrogen, for the amount of water added to the farm is fairly high. Part of the accumulated nitrate also goes to crop uptake. Finally, the profile nitrate concentration gets decreased. Consequently, the amount of nitrate leaching gets decreased.

\subsubsection{Cumulative $\mathrm{NO}_{3} \mathrm{~N}$ Leaching Loss Variations Based on Land Uses}

The differences in land use causes variations on the amount of nitrate leaching. The amount of nitrogen added, either from organic or inorganic forms, to different land uses may probably be different. Moreover, the nutrient uptake capacity of different crops is different. Therefore, the amount of nitrate leaching may also vary accordingly.

The types of land uses taken into consideration, in this study, were the sugarcane and orchard farms. The cumulative simulation results from these two land uses were taken at the $10^{\text {th }}, 20^{\text {th }}, 30^{\text {th }}, 40^{\text {th }}$ and $47^{\text {th }}$ years of simulation periods (Table 4).

Using the LEACHN model outputs (Table 4) as an input to ArcGIS 10.1, maps (Figures 14-18) were developed to visually display the timely variations in cumulative $\mathrm{NO}_{3 \_} \mathrm{N}$ leaching losses based on the variations in

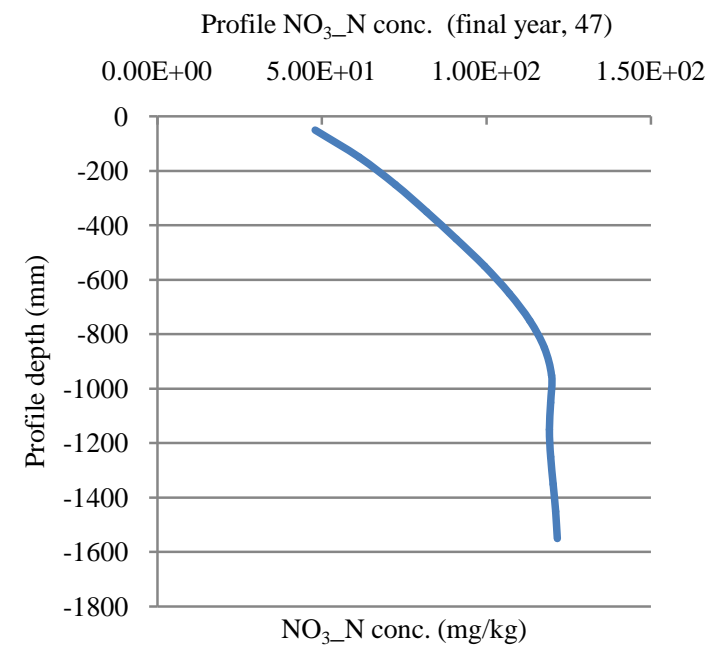

Figure 13. Profile nitrate concentration (Orchard).

Table 4. Cumulative $\mathrm{NO}_{3} \_\mathrm{N}$ leaching losses of different land uses at different simulation periods.

\begin{tabular}{ccc|}
\hline \multirow{2}{*}{ Simulation period } & \multicolumn{2}{c|}{ Land uses } \\
\cline { 2 - 3 } & $\begin{array}{c}\text { Cum.NO }{ }_{3} \text { N leach. (kg/ha) } \\
\text { from the sugarcane farm }\end{array}$ & $\begin{array}{c}\text { Cum.NO }{ }_{3} \_N \text { leach. (kg/ha) } \\
\text { from the orchard farm }\end{array}$ \\
\hline 0 & 0 & 0 \\
10 & 39.0 & 27.4 \\
20 & 81.8 & 57.2 \\
30 & 117.1 & 83.8 \\
40 & 149.4 & 105.2 \\
47 & 178.8 & 127.8 \\
\hline
\end{tabular}




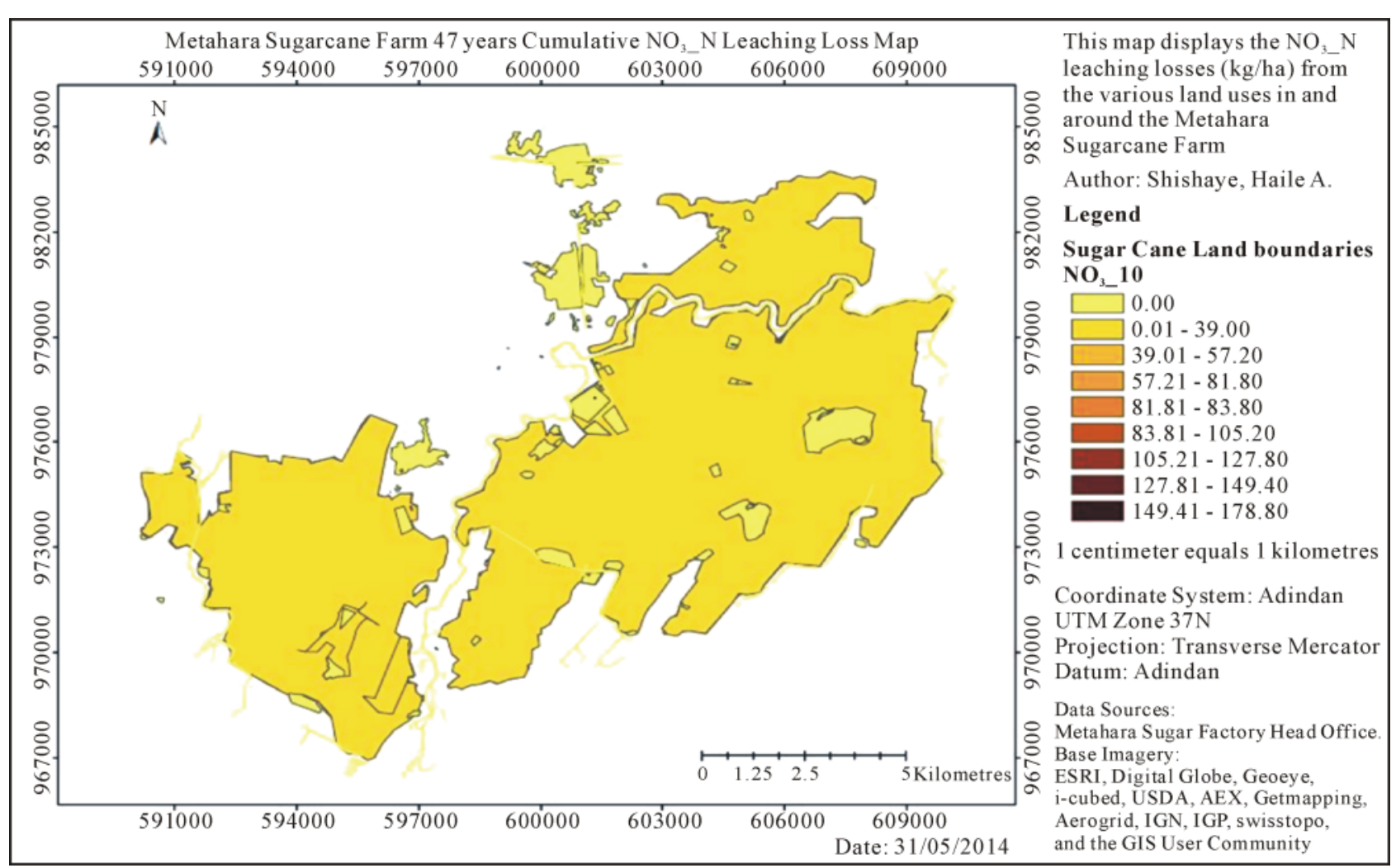

Figure 14. $\mathrm{NO}_{3 \_} \mathrm{N}$ leaching loss (kg/ha), 10 years after the beginning of the simulation period.

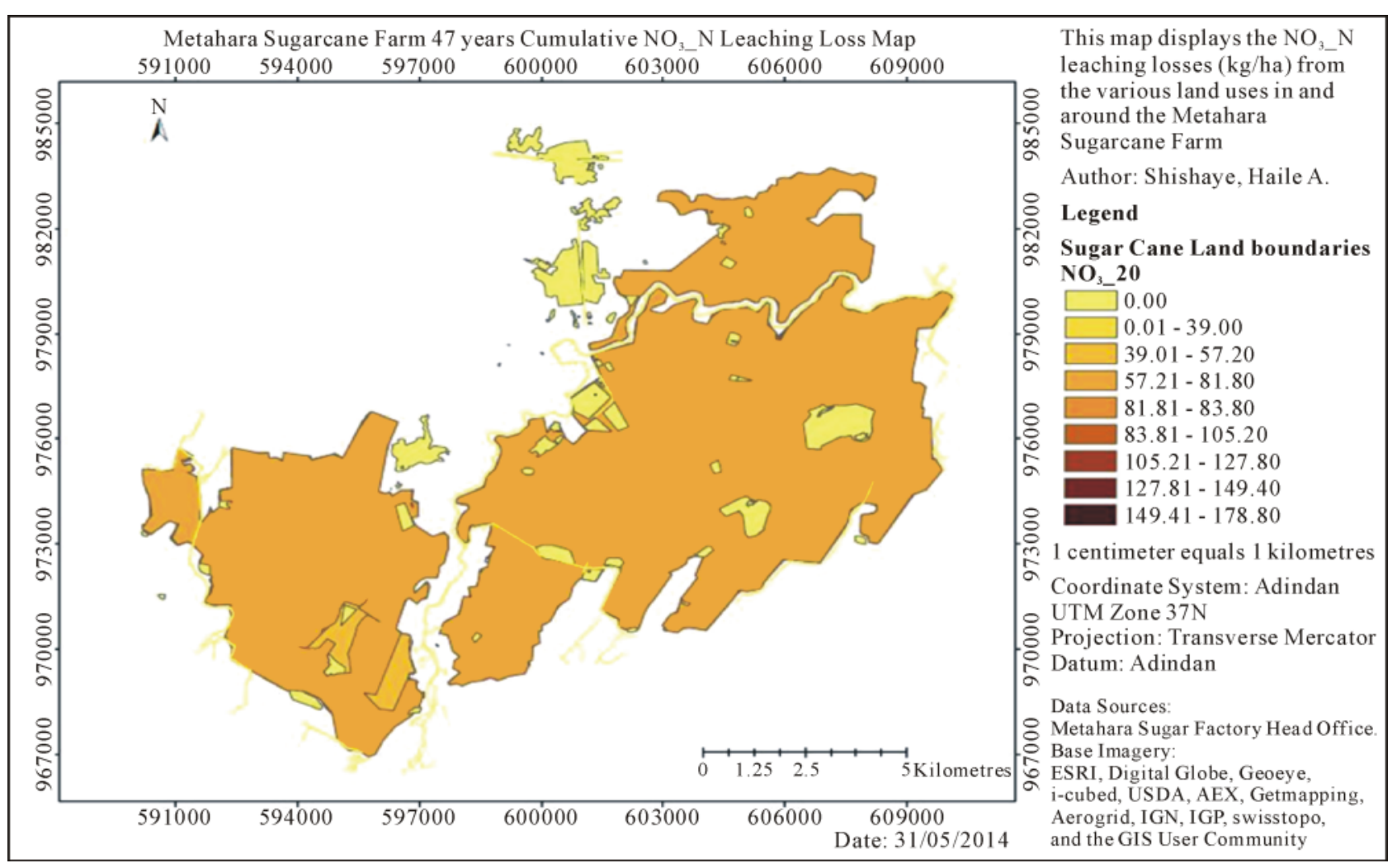

Figure 15. $\mathrm{NO}_{3} \_\mathrm{N}$ leaching loss (kg/ha), 20 years after the beginning of the simulation period. 


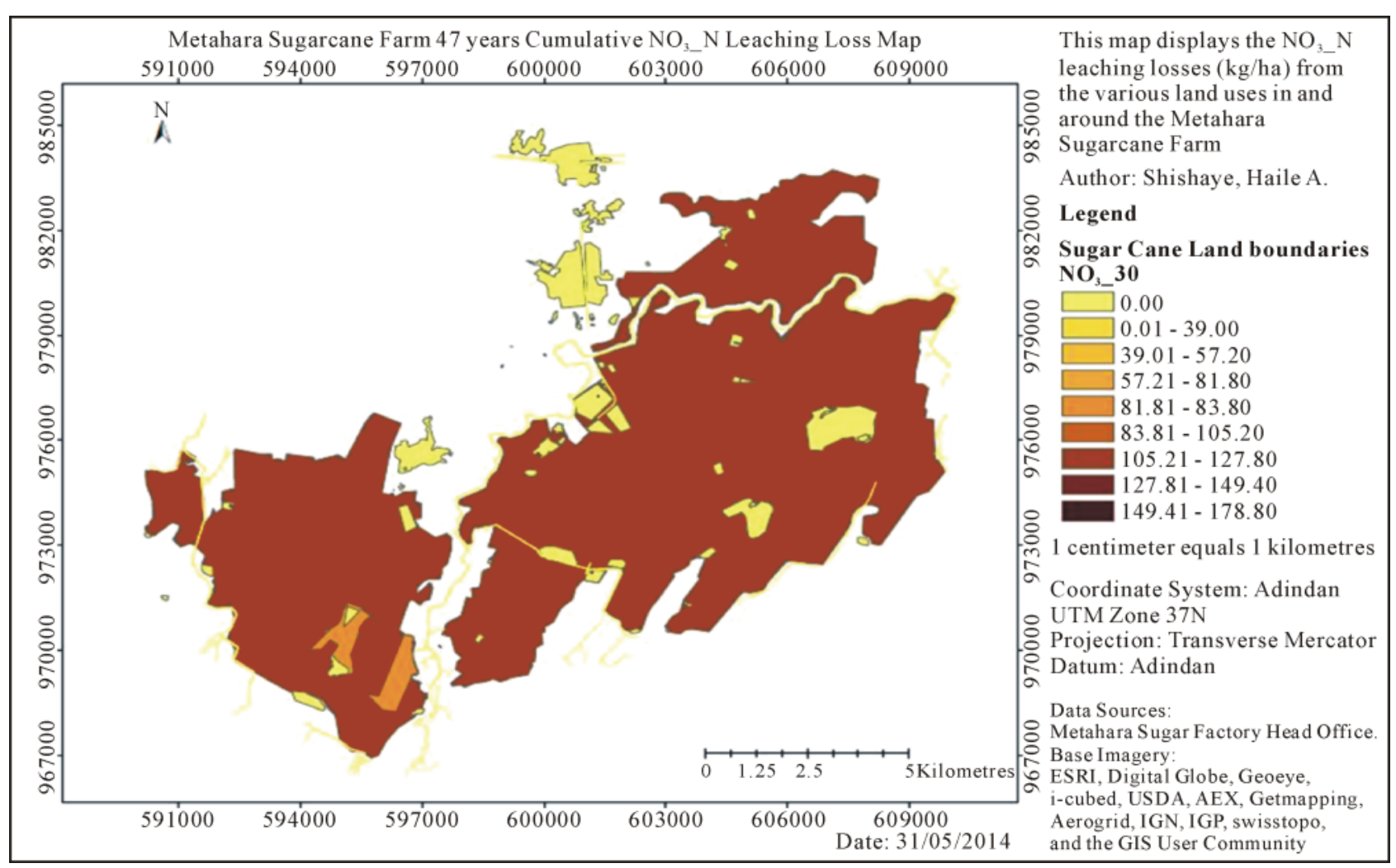

Figure 16. $\mathrm{NO}_{3 \_} \mathrm{N}$ leaching loss (kg/ha), 30 years after the beginning of the simulation period.

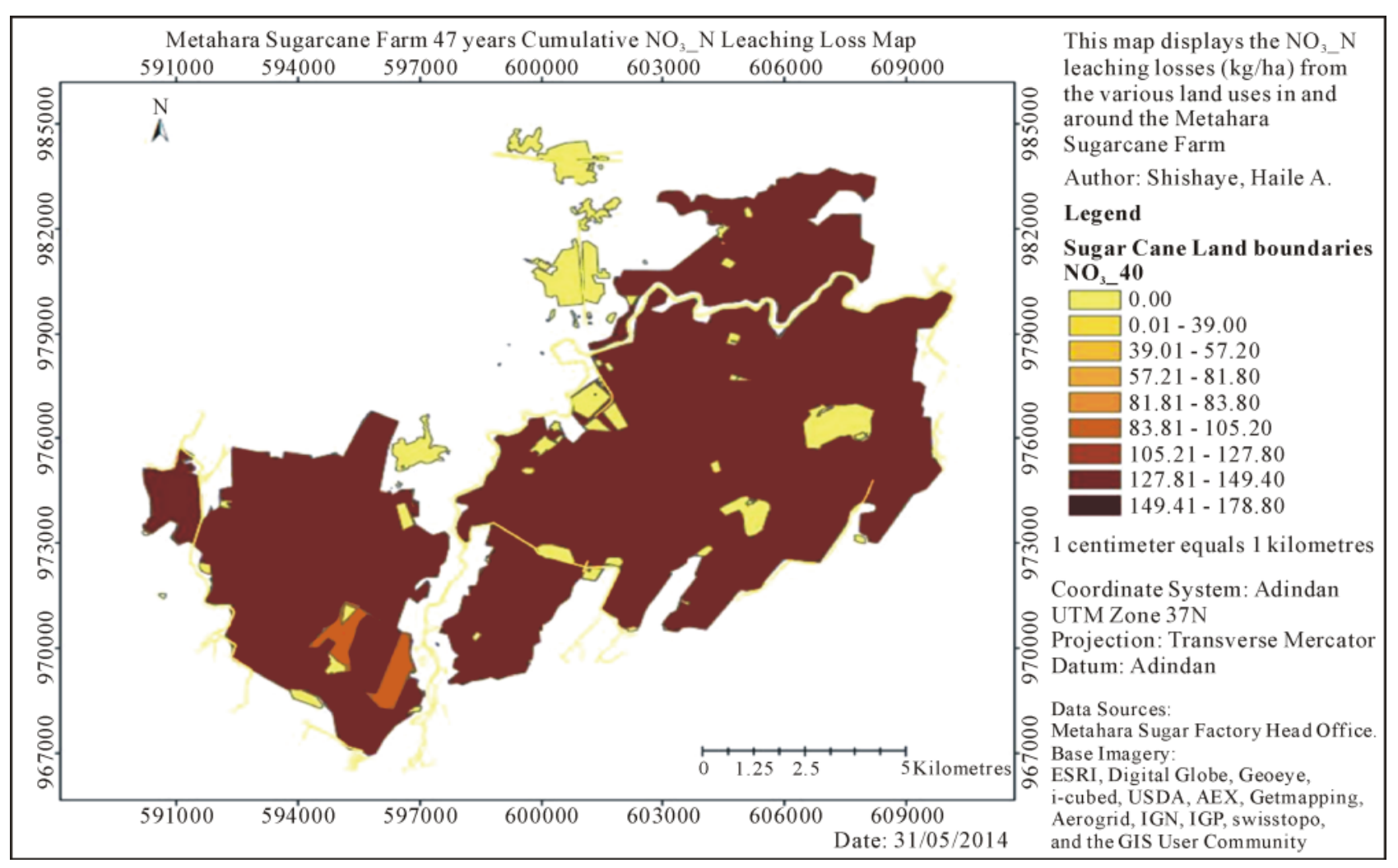

Figure 17. $\mathrm{NO}_{3 \_} \mathrm{N}$ leaching loss (kg/ha), 40 years after the beginning of the simulation period. 


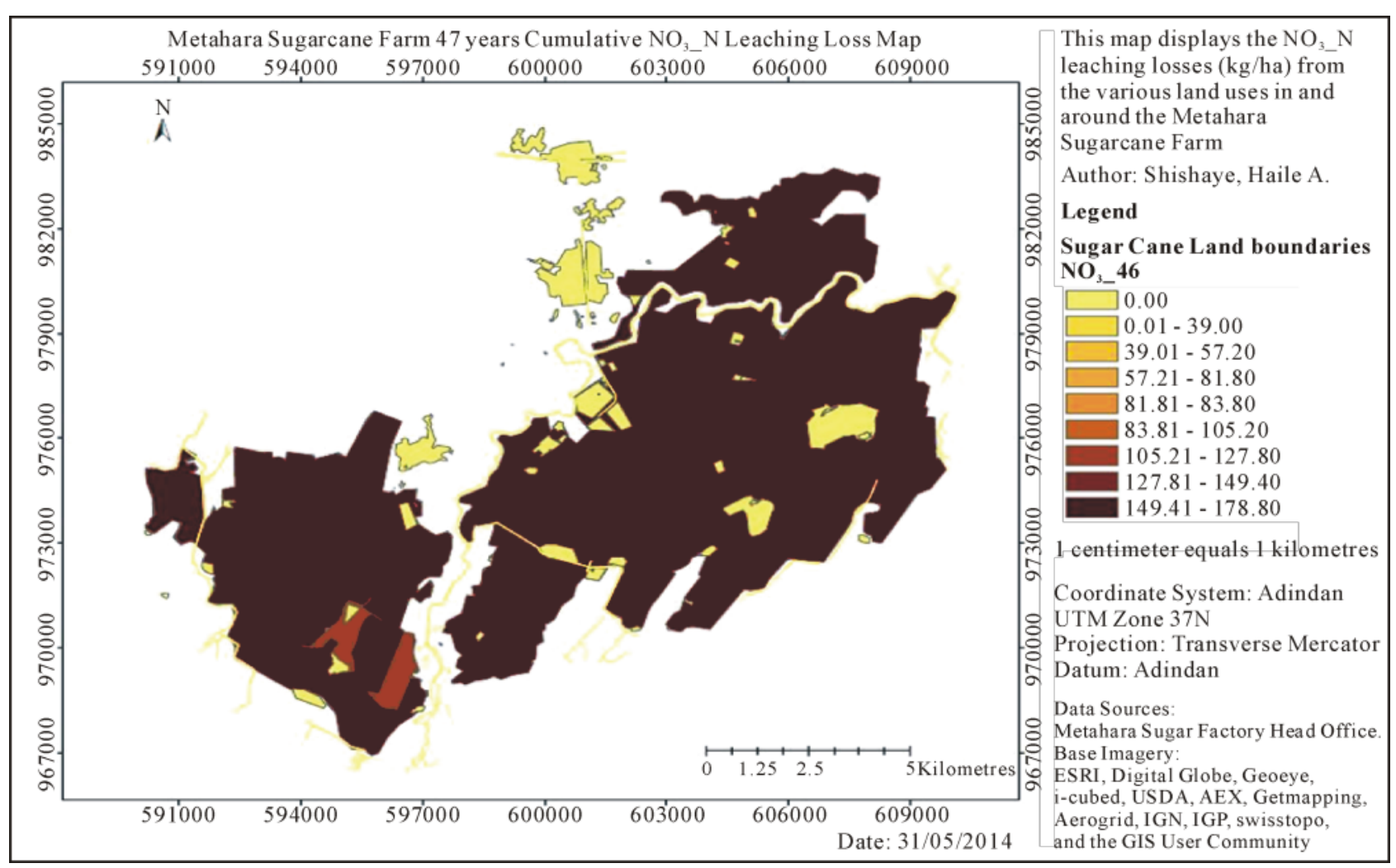

Figure 18. $\mathrm{NO}_{3 \_} \mathrm{N}$ leaching loss $(\mathrm{kg} / \mathrm{ha}), 47$ years after the beginning of the simulation period.

land uses. In this case, land uses apart from those listed in (Table 4) were given a zero value of nitrate nitrogen leaching losses, for the major concerns were given to the agricultural land uses.

\subsection{Factors Influencing the Amount of Nitrate Leaching Losses}

As shown in the simulation results, the low nutrient uptake capacity of sugarcane is leaving more than $60 \%$ of the nutrient applied vulnerable to loss (either to leaching or gaseous losses). Furthermore, the nutrient uptake capacity of most orchard crops is as low as $20 \%$ of applied nitrogen fertilizer [36]. Therefore, just like sugarcane crops, orchard farming has also high contributions to the environmental pollutions including groundwater contamination owing to nitrate leaching.

However, the 47 years simulated nitrate leaching losses from both sugarcane and orchard farming and the actual groundwater nitrate concentration were found to be by far less than the maximum contaminant level standards. This implies that there are different factors affecting the amount of nitrate leaching loss from the farm. Information about the factors affecting the amount of water draining through and below the root zone is, therefore, very essential to know the amount of nitrate leaching to the underlying groundwater, for the factors affecting the amount of water draining into the underlying aquifer can also affect the amount of nitrate leaching with [37]. Some of the factors affecting the amount of water draining and nitrate leaching through the root zone are soil texture, amount of water added, crop types and amount and timing of rainfall. Additionally, the amount of nitrate leaching to the underlying aquifer can also be affected by the amount and type of fertilizer added.

\subsubsection{Soil Texture}

Soil texture affects the soil-water retention capacity. Consequently, the amount of nitrate leaching loss can also be affected. The soil texture in the study area is dominated by clay [24]. Clay (poorly drained) soil types have low hydraulic conductivity value. So, poorly drained soils can reduce the risks of groundwater contamination, even in areas with high nitrogen inputs. For example, the main reason why the groundwater in Southern Indiana has a median nitrate concentration of $<0.05 \mathrm{mg} / \mathrm{L}$, while the $\mathrm{N}$ fertilizer application is high, is because of that the 
soil type in the area is poorly drained soil [18]. Similarly, the poorly drained soil type in the Metahara sugarcane farm is influencing the amount of nitrate leaching losses. The soil type on the farm below $0.6 \mathrm{~m}$ from the ground surface is dominated by mottled clay with a low hydraulic conductivity. This situation can affect the draining water and the amount of nitrate leaching with to be stored in the root zone. As a result, it increases denitrification and immobilization processes and decreases the amount of nitrate leaching from the farm.

\subsubsection{Type of Fertilizer}

The type of fertilizer used in the study area is Ammonium Sulfate Nitrate (ASN). It has high sulfur content in a sulfate form, which is the most available form for plants [25]. Its chemical formula is $\mathrm{H}_{12} \mathrm{~N}_{4} \mathrm{O}_{7} \mathrm{~S}$. It is the product of Ammonium Sulfate $\left(\left(\mathrm{NH}_{4}\right)_{2} \mathrm{SO}_{4}\right)$, a particularly useful in highly alkaline soils and Ammonium Nitrate $\left(\mathrm{NH}_{4} \mathrm{NO}_{3}\right)$, a fertilizer recommended for soils that have low levels of nitrate.

Nitrogen in ASN fertilizer appears in two forms. i.e., in the form of $\mathrm{NO}_{3} \mathrm{~N}$, which acts quickly and not absorbed in the soil, and in the form of $\mathrm{NH}_{4} \_\mathrm{N}$, which acts slowly and can be easily bind with soil particles in the process of physical and chemical sorption.

ASN fertilizer contains $26 \%$ nitrogen, from which $19 \% \mathrm{~N}$ appears as ammonium nitrogen and $7 \% \mathrm{~N}$ in nitrate forms [25]. This fact implies that $\left(\frac{19}{26} * 100=73 \%\right)$ of the nitrogen from the applied fertilizer appears as $\mathrm{NH}_{4 \_} \mathrm{N}$ and the remaining $\left(\frac{7}{26} * 100=27 \%\right)$ in nitrate form. In this regard, $76 \mathrm{kgN} / \mathrm{ha}$ for sugarcane plant, 95 $\mathrm{kgN} / \mathrm{ha}$ for the first and second ratoon crops and $114 \mathrm{kgN} / \mathrm{ha}$ for the third ratoon crops are applied in ammonium nitrogen form; while, the remaining $28 \mathrm{kgN} / \mathrm{ha}$ for sugarcane plant, $35 \mathrm{kgN} / \mathrm{ha}$ for the first and second ratoon crops and $42 \mathrm{kgN} / \mathrm{ha}$ for the third ratoon crops are applied in nitrate forms. Because of that ASN contains high ammonium nitrogen, it guarantees long-term and sustainable nitrogen supply, which is particularly important for crops with long vegetation season (e.g. maize and sugarcane), and prevents nitrogen from being leached. As a result, the amount of nitrate leaching from the study area in the 47 years simulation period was found to be below the MCL standards and even fairly low.

\subsubsection{Amount of Water Added (Rainfall and/or Irrigation)}

The amount of water that has been added to the profile is high. However, because of the low hydraulic conductivity value of the clay soil, it tends to be stored within the soil profile for a long period of time, until it joins the groundwater slowly. Thus, it keeps the soil moisture content fairly high. This can affect the nutrients within the profile to be immobilized back to the organic form of nitrogen and denitrified into gaseous forms of nitrogen instead of leaching down to the underlying aquifer. And that is why we see from the simulation results that high amount of nutrient is being changed into gaseous forms of $\mathrm{N}$ and immobilized back to the organic forms of Nitrogen (Figure 19).

\subsection{Suggested Groundwater Protection Practices}

Groundwater is an important source of water supply for major cities, industries and rural towns in different parts of the world. The existence of many isolated communities and rural properties rely on the availability of good quality groundwater. However, even though it enhances agricultural productivity, increased chemical fertilizer use is imposing significant health and environmental risks, owing to groundwater nitrate contamination. Thus, although reduction of anthropogenic loading of nitrate to groundwater aquifers will not reduce contamination in the short term, due to long travel times, reduction efforts are very critical components of any long term solution to the problem of high nitrate concentration in groundwater.

In fact, the current groundwater nitrate concentration in the study area is still safe, but protecting the underlying aquifer today will contribute for the future groundwater quality. It saves the future lives and water treatment capitals.

Unlike the natural sources of groundwater nitrate, nitrogen from inorganic fertilizer applications and animal wastes can be managed through the choice of appropriate agricultural practices [38] [39]. Therefore, using the following agricultural and other practices will decrease or at least maintain the current groundwater nitrate concentration in the study area. 


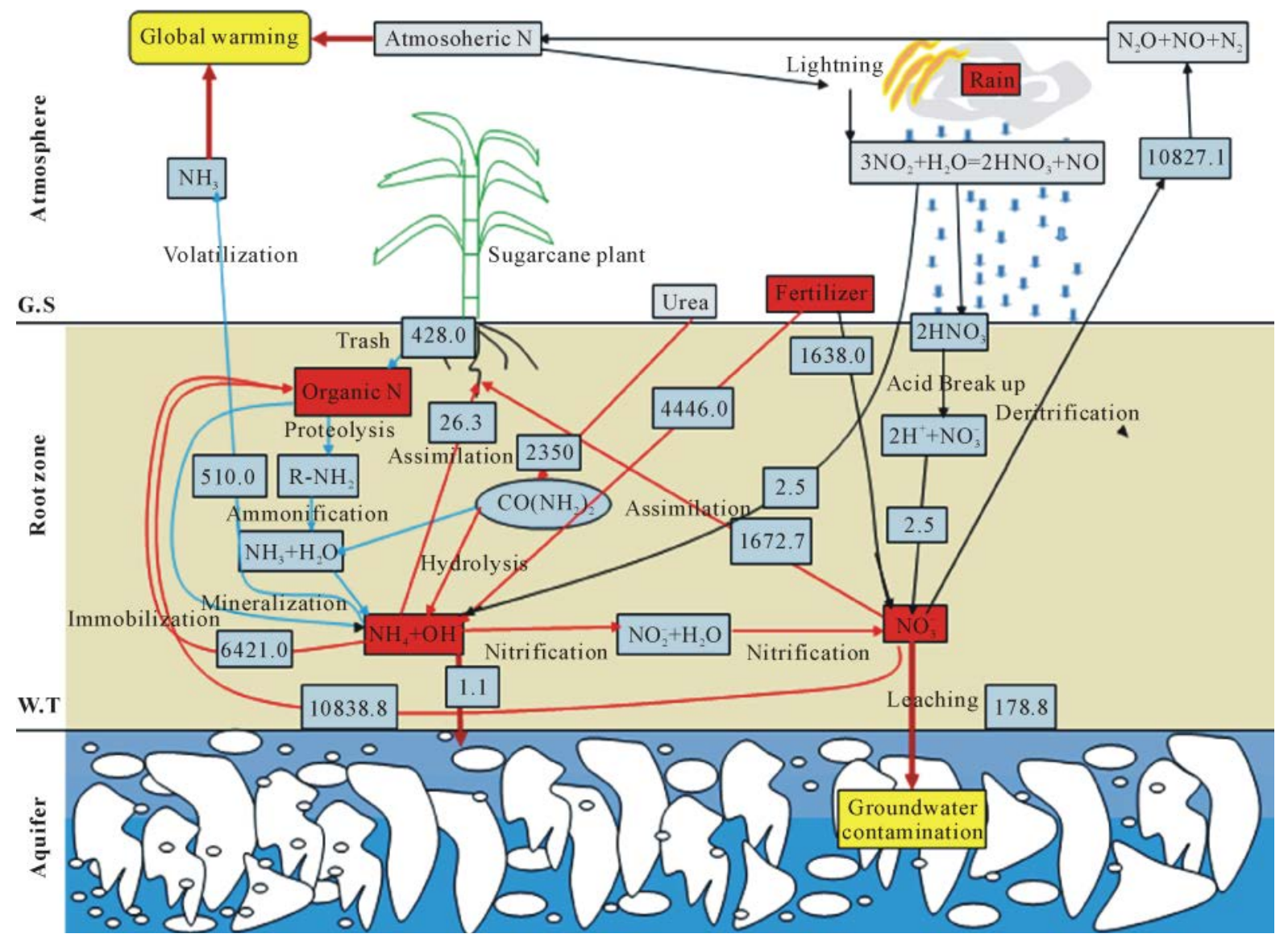

Figure 19. The contributions of the different forms of nitrogen to the environmental pollution. NB: The values in Figure 19 were taken from the simulation for the sugarcane farm.

\subsubsection{Balanced Nitrogen Fertilizer Application}

Balancing the application of nitrogen fertilizer with the amount and time of crop demand prevents losses from leaching, volatilization, denitrification and some other losses. These losses are not only health and environmental concerns, but also direct financial loss to the producer. Improving fertilizer application and management contributes to a sustainable and ecologically sound agriculture, and an effective use of resources and capital. The nitrogen application rate in the study area seems to be more than the crop demand. Thus, a balanced nitrogen fertilizer application is one of the main strategies to reduce the load of nitrate to the underlying aquifer in the study area so as to decrease or at least maintain the groundwater nitrate concentration.

\subsubsection{Crop Rotation and Intercropping}

Unlike sugarcane, crops such as corn, winter wheat and sorghum require high nitrogen inputs. It is possible to reduce nitrogen use in a farming system by rotating these crops with those requiring less nitrogen, such as legumes, which may even require no added nitrogen [19] [40]. This process may result in less nitrogen accumulation in the soil profile and less nitrate leaching. Similarly, rotating sugarcane with high nitrogen demanding crops can reduce the amount of nitrate leaching from sugarcane farms. However, this practice may not be feasible when ratoon crops are used for sugarcane production in the next round/s. Therefore, the other possibility, in this case, is double cropping or intercropping process [41]. Sugarcane crops can be intercropped with crops having high nitrogen uptake capacities. Thus, this process will obviously decrease the amount of nitrate leaching loss.

\subsubsection{Organic Farming}

In this case, organic farming refers to the use of organic forms of nitrogen fertilizers for agricultural production. 
Organic forms of nitrogen are valuable sources of cheap nutrients that can substitute chemical fertilizers. In most cases, the release of nitrate from the organic sources is slow, which reduces the possibility of nitrate build-up in the soil profile. With proper management, the return of organic materials to soil tends to increase the soil organic matter, microbial biomass, level of biological activity, and to keep more of the nitrogen in the organic form, which does not leach and is released more slowly to the crop. For example, [42] showed that burning or removal of wheat or sorghum residues decreased the soil organic carbon and increased leaching of nitrate.

Farmers can control the rate of nitrogen release and the potential leaching loss by using crop residues, manures and other organic materials as a source of nitrogen [42]. The systems used by the organic farmers in the United States are the best examples showing the advantages of using organic forms of nitrogen for agricultural production [43] [44].

Therefore, even though the type of $\mathrm{N}$ fertilizer used in Metahara sugarcane farm is ASN, a fertilizer with around $73 \%$ of $\mathrm{N}$ in an ammonium form, the use of organic forms of $\mathrm{N}$ will keep the underlying aquifer safe from nitrate contamination. Crop residues, filter cakes and still effluents could be helpful sources of organic nutrients in Metahara sugarcane farm.

\subsubsection{Using Sprinkler and/or Drip Irrigation Systems}

The type of irrigation system being used in the study area is surface irrigation system (i.e., furrow irrigation for sugarcane crops and basin irrigation system for orchard plants). Surface irrigation systems are expected to be sources of groundwater nitrate contamination, especially if practiced on highly permeable soils. In fact, the soil type in the study area is poorly drained. However, using surface irrigation system would lead to runoff losses, water logging problems and low productivity due to wilting of crops owing to lack of soil aeration. The runoff losses may contaminate the downstream surface water bodies and groundwater, when a losing surface water body, in a hydrogeologically connected scenario, discharges to the underlying aquifers. Moreover, even though it will take a long time for the drainage water to join the underlying groundwater in the study area, for the soil types are poorly drained, nitrate leaching is high in surface irrigation systems than the pressurized irrigation systems (e.g., sprinkler and drip irrigation systems).Therefore, using sprinkler and/or drip irrigation systems would help in decreasing water losses, water logging and nitrate leaching problems in the study area. The pressurized irrigation systems are known to keep nitrate in the root zone, rather than have it leach downward to the underlying aquifer and flow laterally or overflow due to runoff to the downstream surface water bodies.

\section{Conclusions}

The differences in land use, soil type and the amount of water and fertilizer added to the farmland make a difference on the amount of nitrate leaching to the underlying aquifer. A variation in nitrate leaching loss is found based on the variations in land use and crop types, for there is a difference in the nutrient uptake capacities of the crops.

In general, modeling of nitrate leaching loss under the given soil types and land use scenarios has produced results that are considered to be realistic for the study area. Taking the soil type, moisture content, land use, type of fertilizer used and some other factors into consideration, the amount of nitrate leaching found from the simulation can be considered as real/representative for the study area.

However, even though the simulation results show that the current drainage water and groundwater nitrate concentration are low, potential anthropogenic nitrogen sources in the study area must be carefully managed to minimize nitrate that leaches into the groundwater and ensures future groundwater quality. Furthermore, even though the likelihood of detecting contamination in the study area is low, for the soil type is poorly drained. It is better to be safe than remorseful.

\section{References}

[1] Letey, J. and Vaughan, P. (2013) Soil Type, Crop and Irrigation Technique Affect Nitrogen Leaching to Groundwater. California Agriculture, 67, 231-241. http://dx.doi.org/10.3733/ca.E.v067n04p231

[2] Bolger, P. and Stevens, M. (1999) Contamination of Australian Groundwater Systems with Nitrate. LWRRDC Occasional Paper 03/99.

[3] Xu, L.G., Niu, H.L., Xu, J. and Wang, X.L. (2013) Nitrate-Nitrogen Leaching and Modeling in Intensive Agriculture Farmland in China. The Scientific World Journal, 2013, Article ID: 353086. 
[4] Oenema, O., Kros, H. and de Vries, W. (2003) Approaches and Uncertainties in Nutrient Budgets: Implications for Nutrient Management and Environmental Policies. European Journal of Agronomy, 20, 3-16. http://dx.doi.org/10.1016/S1161-0301(03)00067-4

[5] Mitchell, A.R., Light, J.E. and Page, T. (1991) Alternate and Alternating Furrow Irrigation of Peppermint to Minimize Nitrate Leaching. USDA-CSRS, Special Water Quality Research Program, the Oregon Department of Environmental Quality.

[6] Czymmek, K., Ketterings, Q., Horald, V., DeGloria, S. and Albrecht, G. (2005) The New York Nitrate Leaching Index. Cornell University Cooperative Extension, Agronomic Fact Sheet Series 11.

[7] Feaga, J.B., Selker, J.S., Dick, R.P. and Hemphill, D.D. (2010) Long-Term Nitrate Leaching under Vegetable Production with Cover Crops in the Pacific Northwest, Soil and Water Management and Conservation. Soil Science Society of America, 74, 186-195. http://dx.doi.org/10.2136/sssaj2008.0178

[8] Jones, C. (2011) Crop and Fertilizer Management Practices to Minimize Nitrate Leaching. Montana State University Extension, Agriculture and Natural Resources, 600-111SA.

[9] Campbell, C.A., Selles, F., Zentner, R.P., De Jong, R., Lemke, R. and Hamel, C. (2006) Nitrate Leaching in the Semiarid Prairie: Effect of Cropping Frequency, Crop Type, and Fertilizer after 37 Years. Canadian Journal of Soil Science, 86, 701-710. http://dx.doi.org/10.4141/S05-008

[10] Robinson, N., Brackin, R., Vinall, K., Soper, F., Holst, J., Gamage, H., Paungfoo-Lonhienne, C., Rennenberg, H., Lakshmanan, P. and Schmidt, S. (2011) Nitrate Paradigm Does Not Hold up for Sugarcane, PLoS ONE, 6, e19045. http://dx.doi.org/10.1371/journal.pone.0019045

[11] Grigg, B., Southwick, L., Fouss, J. and Kornecki, T. (2003) Drainage System Impacts on Surface Runoff, Nitrate Loss, and Crop Yield on a Southern Alluvial Soil. American Society of Agricultural Engineers, 46, 1531-1537.

[12] Barbara, D. and Nancy, M. (2010) Drinking Water Facts. Utah State University, Water Quality Extension, Logan.

[13] Mahler, R.L., Colter, A. and Hirnyck, R. (2007) Nitrate and Groundwater. University of Idaho, Collage of Agricultural and Life Sciences, Moscow.

[14] ARD-EHP (2006) Nitrate and Nitrite: Health Information Summary. New Hampshire, Department of Environmental Services, Environmental Fact Sheet.

[15] Cooper, C. (1993) Biological Effects of Agriculturally Derived Surface Water Pollutants on Aquatic Systems-A Review. Journal of Environmental Quality, 22, 402-408. http://dx.doi.org/10.2134/jeq1993.00472425002200030003x

[16] McMahon, P., Bohlke, J., Kauffman, L., Kipp, K., Landon, M., Crandall, C., Burow, K. and Brown, C. (2007) Source and Transport Controls on the Movement of Nitrate to Public Supply Wells in Selected Principal Aquifers of the United States. Water Resources Research, 44, 40-44.

[17] Cregg, B., Rios, C., Hart, J. and Briggs, D. (20040 Fate of Nitrates in Field Nursery Production Systems. USDA Forest Service Proceedings, RMRS-P-33, 50-51.

[18] Mueller, D., Hamilton, P., Helsel, D., Hitt, K. and Barbara, C. (1995) Nutrients in Ground Water and Surface Water of the United States, an Analysis of Data through 1992. U.S. Geological Survey, Water Resources Investigations Report 95, 4031.

[19] Johnson, A., Cabrera, M., Hargrove, W., McCracken, D. and Harbers, G. (1993) Estimating Nitrate leaching and Soil Water Dynamics with LEACHM. Institute of Natural Resources, the University of Georgia, Athens, 371.

[20] Hutson, J.L. (2003) Leaching Estimation and Chemistry Model: A Process-Based Model of Water and Solute Movement, Transformations, Plant Uptake, and Chemical Reactions in the Unsaturated Zone, Version 4, Department of Crop and Soil Sciences, Cornell University, Ithaca.

[21] Hutson, J. and Wagenet, R. (1992) LEACHM (Leaching Estimation and Chemistry Model): A Process-Based Model of Water and Solute Movement, Transformations, Plant Uptake and Chemical Reactions in the Unsaturated Zone, Version 3.0, Department of Soil, Crop and Atmospheric Sciences, Cornell University, Ithaca.

[22] Campbell, G.S. (1974) A Simple Method for Determining Unsaturated Conductivity from Moisture Retention Data. Soil Science, 117, 311-314. http://dx.doi.org/10.1097/00010694-197406000-00001

[23] Hutson, J.L. and Cass, A. (1987) A Retentivity Function for Use in Soil-Water Simulation Models. European Journal of Soil Science, 38, 105-113. http://dx.doi.org/10.1111/j.1365-2389.1987.tb02128.x

[24] Booker Tate Limited (2009) Re-Evaluation of Plantation soils at Metahara Sugar Factory, Masters Court, Church Road Thame, Oxon OX9 3FA, UK.

[25] Aurepio (2012) Ammonium Sulfate Nitrate. http://www.aurepio.pl/en/nitrogen-fertilizers/ammonium-sulphate-nitrate-s250

[26] Sentelhas, P.C. and Folegatti, M.V. (2003) Class a Pan Coefficients (Kp) to Estimate Daily Reference Evapotranspiration (ETo). Revista Brasileira de Engenharia Agrícola e Ambiental, 7, 111-115. 
http://dx.doi.org/10.1590/S1415-43662003000100018

[27] Snyder, R.L. (1992) Equation for Evaporation Pan to Evapotranspiration Conversions. Journal of Irrigation and Drainage Engineering, 118, 977-980. http://dx.doi.org/10.1061/(ASCE)0733-9437(1992)118:6(977)

[28] Biggs, I. (2003) An Investigation of Sugarcane Nitrogen Physiology: Sources, Uptake and Metabolism. The Queensland University, School of Integrative Biology, Ph.D. Thesis, School of integrative biology, Queensland University, Australia.

[29] WHO (1984) Guide Lines for Drinking Water Quality, Vol. 1, Recommendations. World Health Organization, Geneva.

[30] WHO (2004) Nitrates and Nitrites in Drinking-Water, Rolling Revision of the WHO Guidelines for Drinking-Water Quality. WHO/SDE/WSH/04.08/56.

[31] USEPA (2007) Drinking Water Standards and Health Advisories Table. Bruce Macler Drinking Water Office, 29.

[32] Webb, T.H. and Lilburne, L.R. (1999) Use of the LEACHM Model and the DRASTIC Index to Map Relative Risk of Groundwater Contamination by Pesticide Leaching. Journal of Hydrology, New Zealand (NZ), 38, 271-288.

[33] Toride, N. and Chen, D. (2011) Fate Transport Modeling of Nitrogen and Organic Matter in Soils. Mie University, Tsu.

[34] JoAnn, M., Holloway, L. and Randy, A. (1999) Geologic Nitrogen in Terrestrial Biogeochemical Cycling. The Geological Society of America, 20, 567-570.

[35] FAO (1998) Crop Evapotranspiration-Guidelines for Computing Crop Water Requirements. Department of Natural Resources Management and Environment. http://www.fao.org/docrep/X0490E/X0490E00.htm

[36] Lois, B. (2012) Nitrogen Uptake and Assimilation in Woody Crops. University of Minnesota, Minneapolis and Saint Paul.

[37] Williams and Kissel (1984) Managing Nitrogen for groundwater quality and farm profitability: Water Percolation, an Indicator of Nitrogen-Leaching Potential. Soil Science Society of America, Inc., Madison, 59-61.

[38] Rice, C.W. and Havlin, J.L. (1994) Integrating Mineralizable Nitrogen Indices into Fertilizer Nitrogen Recommendations. Soil Science Society of America, Special Publication No. 40.

[39] Dzurella, K.N., Medellin-Azuara, J., Jensen, V.B., King, A.M., De La Mora, N., Fryjoff-Hung, A., Rosenstock, T.S., Harter, T., Howitt, R., Hollander, A.D., Darby, J., Jessoe, K., Lund, J.R. and Pettygrove, G.S. (2012) Nitrogen Source Reduction to Protect Groundwater Quality. Technical Report 3 in: Addressing Nitrate in California’s Drinking Water with a Focus on Tulare Lake Basin and Salinas Valley Groundwater, Report for the State Water Resources Control Board Report to the Legislature, Center for Watershed Sciences, University of California, Davis.

[40] Power, J.F. (1987) The Role of Legumes in Conservation Tillage Systems. Soil Science Society of America, Ankeny, 153.

[41] Stewart, B.A., Viets, F.G. and Hutchinson, G.L. (1968) Agriculture’s Effect on Nitrate Pollution of Ground Water Jour. Soil and Water Conservation, 23, 13.

[42] Hooker, M.L., Herron, G.M. and Penas, P. (1982) Effects of Residue Burning, Removal, and Incorporation on Irrigated Cereal Crop Yields and Soil Chemical Properties. Soil Science Society of America Journal, 46, 122-126. http://dx.doi.org/10.2136/sssaj1982.03615995004600010023x

[43] U.S. Department of Agriculture (1980) Report and Recommendations on Organic Farming. Prepared by USDA Study Team, July 1980, 3100-944/96, U.S. Government Printing Office, Washington, DC.

[44] Papendick, I. and Elliot, F. (1984) Alternative Production Systems to Reduce Nitrates in Ground Water. American Journal of Alternative Agriculture, 2, 19-24. 